\title{
Contrasting P-T conditions of Oriental Terrane and Central Superterrane (Ribeira Belt), NW of Rio de Janeiro state, Brazil
}

\author{
Rodson de Abreu MARQUES'1, Beatriz Paschoal DUARTE², Miguel Antônio TUPINAMBÁ², \\ Edgar Batista de MEDEIROS JUNIOR ${ }^{3} \&$ Sandro MAURI ${ }^{1,2}$ \\ Departamento de Geologia da Universidade Federal do Espírito Santo. Alto Universitário s/n, \\ CEP 29500-000, Alegre, ES, Brasil (rodson.marques@ufes.br, sandromauriferreira@gmail.com). \\ ${ }^{2}$ Faculdade de Geologia, Departamento de Geotectônica e Geologia Regional, Universidade do Estado do \\ Rio de Janeiro. Rua São Francisco Xavier, n 524, $4^{\circ}$ andar, CEP 19550-900, Maracanã, Rio de Janeiro, RJ, \\ Brasil (biapasch@gmail.com, tupinambamiguel@gmail.com) \\ ${ }^{3}$ Departamento de Solos, Universidade Federal de Viçosa. Av. Peter Henry Rolfs s/n, Campus Universitário, \\ CEP 36570-900, Viçosa, MG, Brasil (edgar.junior@ufv.br).
}

\begin{abstract}
Neoproterozoic-Cambrian rocks from the Oriental Terrane and the Central Superterrane of the Ribeira Belt occur in northwest of Rio de Janeiro state. This paper presents new data on field research, petrology, mineral chemistry and conventional geothermobarometry, fundamental to understanding the geology of the region. The metabasic rocks from the Cambuci Domain are associated with the Central Superterrane retroarc basin and record two metamorphic events: $M_{0}$ (before the formation of the main foliation, under conditions of $788^{\circ} \mathrm{C}$ ) and $\mathrm{M}_{1}$ (contemporary to the main foliation, with peak at $718-752{ }^{\circ} \mathrm{C}$ and $6.62 \mathrm{kbar}$ ). The rocks from the Costeiro Domain, interpreted as the Rio Doce arc (Angelim Suite) and the retroarc basin (São Fidélis Goup) of the Oriental Terrane record a metamorphic peak at granulite facies yielding the highest pressure and temperature among the studied domains $\left(752-784^{\circ} \mathrm{C}\right.$ and $\left.8.2-9 \mathrm{kbar}\right)$. The Italva Domain amphibolites represents the retroarc basin of the Oriental Terrane. Temperature and pressure values obtained for the Italva Domain metamorphic peak record $731^{\circ} \mathrm{C}$ and $6.78 \mathrm{kbar}$, respectively, in the transition zone between upper amphibolite and granulite facies conditions. This work presents the newest record of metamorphic evolution for the Oriental Terrane of the Ribeira Belt, suggesting an anticlockwise P-T-t path and near-isobaric cooling (IBC) for the rocks of the Cambuci Domain. Therefore, these results contribute to the understanding of the evolution of orogenic belts during the amalgamation of the Gondwana in the Neoproterozoic.
\end{abstract}

Keywords. Ribeira Belt, Oriental Terrane, Central Superterrane, Mineral chemistry, geothermobarometry.

Resumo. CONTRASTE DAS CONDIÇÕES P-T DO TERRENO ORIENTAL E DO SUPERTERRENO CENTRAL (FAIXA RIBEIRA), NW DO ESTADO DO RIO DE JANEIRO, BRASIL. Rochas de idade neoproterozoicacambriana do Terreno Oriental e do Superterreno Central da Faixa Ribeira ocorrem no noroeste do estado do Rio de Janeiro. Este trabalho insere na literatura novos dados de campo, petrologia, química mineral e de geotermobarometria convencional, fundamentais ao entendimento da geologia da região. As rochas metabásicas do Domínio Cambuci, associadas à bacia de retroarco do Superterreno Central, registram dois eventos metamórficos: $\mathrm{M}_{0}$ (anterior à formação da foliação principal, sob condições de $788^{\circ} \mathrm{C}$ ) e $M_{1}$ (contemporânea à foliação principal, com pico em $718-752{ }^{\circ} \mathrm{C}$ e $6.62 \mathrm{kbar}$. As rochas do Domínio Costeiro, interpretadas como representantes do arco Rio Doce (Suíte Angelim) e da bacia de retroarco (Grupo São Fidélis) do Terreno Oriental, registram pico metamórfico em facies granulito e os valores de pressão e temperatura obtidos $\left(752-784{ }^{\circ} \mathrm{C}\right.$ e 8.2-9.0 kbar) foram os mais elevados dentre os domínios estudados. Para o Domínio Italva, representante da bacia de retroarco do Terreno Oriental, os valores de temperatura e pressão obtidos para o pico metamórfico foram $731^{\circ} \mathrm{C}$ e $6.78 \mathrm{kbar}$, com pico metamórfico na zona de transição entre as condições de fácies anfibolito superior e granulito. Este trabalho apresenta a mais nova abordagem da evolução metamórfica no Terreno Oriental da Faixa Ribeira, sugerindo um caminho P-T-t no sentido anti-horário para as rochas dos domínios Cambuci. Portanto, esse resultado contribui para a compreensão da evolução dos cinturões de orogenicos durante a amalgamados no Gondwana durante o Neoproterozoico.

Palavras-chave. Faixa Ribeira, Terreno Oriental, Superterreno Central, Química Mineral, Geotermobarometria. 


\section{Introduction}

The evolution of metamorphic highgrade terranes has been described in several places around the world. More robust models of lithospheric evolution have been improved by obtaining more accurate pressure and temperature data (Brown, 2014). The application of geothermometers and geobarometers, using the compositions of zoned minerals, to estimate $\mathrm{P}-\mathrm{T}$ conditions through geological time has contributed to the elucidation of Precambrian geodynamics (Spear et al., 1984; Selverstone \& Spear, 1985; Spear, 1989; Brown, 2014; Winter, 2014).

The metamorphic evolution of the Ribeira belt is characterized by three events $\left(M_{0}, M_{1}\right.$ and $\mathrm{M}_{2}$ ) discriminated by microtectonics criteria and the application of $\mathrm{U}-\mathrm{Pb}$ techniques in metamorphic minerals (Machado et al., 1996). The oldest event, $M_{0^{\prime}}$ is recorded only in rocks of the Juiz de Fora Complex and perhaps, in metamorphic rocks of the Cambuci Domain (Duarte et al., 2012). $M_{1}$ stage reached metamorphic peak at $580 \mathrm{Ma}$ (Machado et al., 1996; Valladares, 1996) and generated mineral assemblages of intermediate to high pressures. Its microstructural features, which is contemporary with these assemblages, is marked by the development of the main foliation, during the main deformation event $\left(D_{1}+D_{2}\right)$. $M_{2}$ occurs in metasedimentary rocks and syn-collisional granitoids/charnockites of the Costeiro Domain. $\mathrm{U}$-Pb data for titanite-bearing leucossomes from the Paraiba do Sul Klippe and Costeiro Domain rocks indicated, for $\mathrm{M}_{2}$, an age of 535-520 Ma (Machado et al., 1996).

Two major deformational events were responsible for structuring the central sector of the Ribeira Belt (Heilbron et al., 2000). The first event is related to the main deformation and includes the geometric phases $D_{1}$ and $D_{2}$. It was responsible for the amalgamation and overlapping of the Occidental and Oriental terranes and Central Superterrane, as well as for the development of the main foliation, sometimes of mylonitic characteristics. The late deformation involves the geometric phases $D_{3}$ and $D_{4^{\prime}}$ responsible for refolding the main foliation and developing subvertical shear zones. The terranes and its domains are separated by important reverse to transpressional ductile shear zones, generated during the main deformation - $D_{1}+$ $D_{2}$ (Heilbron, 1993; Heilbron et al., 1998, 2000, 2004; Almeida et al., 1998; Almeida, 2000). The boundary between the Occidental and Oriental terranes, which is considered the main suture of the Brasiliano Orogeny in the belt, is recorded by a NW dipping shear zone, called Central Tectonic Boundary (Almeida et al., 1998).

Based on the study of metabasic and metapelitic rocks of the São Fidélis Group (Costeiro Domain, Oriental Terrane), Santos et al. (2005) determined a P-T metamorphic history with peak conditions ranging in the interval of $750-800^{\circ} \mathrm{C}$ and 8-9 kbar. They have interpreted it as an early $M_{1}$ event, possibly equivalent to the $M_{0}$ event of Duarte et al. (2012) (Heilbron et al., 2020), which obtained significantly lower values for both temperature and pressure $\left(600-700{ }^{\circ} \mathrm{C}\right.$ and 5 to 6.5 kbar).

Few studies have been conducted on the metamorphic evolution of the Ribeira Belt, especially in the northern sector of the Orogen. Therefore, the aim of this work is to characterize the metamorphic conditions for the Italva and Costeiro Domains of the Oriental Terrane, and also for the Cambuci Domain of the Central Superterrane, based on the application of geothermobarometry analysis. This study targeted a set of metapelitic and associated metabasic rocks of the supracrustal sequences of these domains, outcropping at the Itaperuna region, central sector of the Ribeira Belt.

\section{Geological setting}

The Ribeira Belt (Fig.1), South/Southeastern São Francisco Craton (Almeida et al., 1973), was generated in the Neoproterozoic/Cambrian time, during the Brasiliano Orogeny (Almeida, 1971; Almeida et al., 1977), with its main collision event at ca. $580 \mathrm{Ma}$

This orogen comprises four tectonostratigraphic terranes imbricated from SSE to NWW toward the São Francisco Craton (Heilbron et al., 2004): Occidental Terrane, Central Superterrane (now inclunding Cambuci Domain, Paraiba do Sul and Embu terranes - Heilbron et 
al., 2020) Oriental Terrane and Cabo Frio Terrane; the last one amalgamated at $520 \mathrm{Ma}$. The study area is located in the contact between the Central Superterrane and Oriental Terrane and includes the following domains which is structured, from bottom to top as: a) the Cambuci Domain of the Central Superterrane; b) the Costeiro Domain, which includes the Rio Negro Magmatic Arc 790-610 Ma (Tupinambá et al., 1998); and c) the Italva Domain with the Serra da Prata Arc (ca. 856-838 Ma) (Peixoto et al. 2017), included in the Oriental Terrane.

According to Tupinambá et al. (2007) and the stratigraphic nomenclature revised in Duarte et al. (2012), the Cambuci Domain was tectonically interpreted as belonging to the bottom of the Oriental Terrane. It comprises a volcanicsedimentary succession metamorphosed in upper amphibolite to granulite facies, cut by several generations of Neoproterozoic granitoid rocks.

Nevertheless, Heilbron et al. (2020) proposed a new configuration for the Ribeira Belt subdivision, introducing the Domain Central Superterrane, which includes the Cambuci Domain, Paraíba do Sul and Embú terranes. According with these authors, the Central Superterrane represents the Inner Continental Magmatic Arc System with collision stage in the Neoproterozoic (ca. $620-595 \mathrm{Ma}$ ).

Despite of the new configuration, the Cambuci Domain remains with the same stratigraphic units as described by Tupinambá et al. (2007) and Duarte (2012). In the Cambuci Domain, three lithostratigraphic units occur: Bom Jesus do Itabapoana Group; Serra da Bolivia Complex and leucocharnockites of the São João do Paraíso Suite. The Serra da Bolivia Complex is the lower tectonic unit within the Cambuci Domain. It is characterized by a group of orthogneisses and igneous rocks of a wide range of composition, including granitic, tonalitic and basic rocks. Structures are generally foliated or massive (Tupinambá et al., 2007; Duarte et al., 2012). The Bom Jesus do Itabapoana Group is a metasedimentary sequence and its predominant lithotype is a (opx)-(garnet)-biotite gneiss with schlieren, agmatic and phlebitic migmatitic structures. Other conspicuous characteristics are the grain size heterogeneity and the presence of garnet porphyroblasts. Dolomitic marble layers and lenticular bands of amphibolite and metaultramafic rocks often occur associated with the gneiss. Calcsilicate rocks and subordinately gondites occur as lenses, bands or boudins associated to the pelitic gneiss.

The high-grade metamorphism that affected the rocks of the Bom Jesus do Itabapoana Group led to the generation of S-type diatexites, represented by leucogranitoids and leucocharnockitoids of the São João do Paraíso Suite, in which the dominant lithotype shows massive to slightly foliated structure. Marques et al. (2019) described the São João do Paraíso rocks as garnet diatexites associated to marbles bodies with calssilicatic, metabasic enclaves and skarns. The most commom porphyroblasts are garnet, plagioclase, K-feldspar and rare orthopyroxene. The matrix of these granitoids and charnockitoids is fine to medium grained, with a granoblastic texture.

The Costeiro Domain (Oriental Terrane) consists of three major units (Tupinambá et al., 2007, with stratigraphic nomenclature revised in Nogueira, 2012): the São Fidelis Group, which consists of a Neoproterozoic supracrustal sequence and two other units of granitoid rocks generated during several stages of Brasiliano Orogeny, the Rio Negro Complex and the Angelim Suite. The São Fidelis Group (Silva et al., 1978; Batista, 1984, 1986; Reis \& Mansur, 1995) is characterized by successions of metasedimentary rocks (kinzigite, homogeneous biotite-bearing gneiss, (sillimanite)-biotite banded or homogeneous gneiss and quartzite) metamorphosed in upper amphibolite to granulite facies. The Serra da Prata Arc (890-858 $\mathrm{Ma}$ ) is constituted of metaluminous calc-alkaline diorites, tonalites and granodiorites (Peixoto et al., 2017). The Rio Negro Complex includes a set of orthogneisses of varied compositions, generated during the pre-collisional stage of Brasiliano Orogeny - 790 - 610 Ma (Tupinambá et al., 2000). The Angelim Suite consists dominantly of a foliated (garnet)-hornblendebiotite granite to tonalile. It may be homogeneous and locally displays a gneiss structure. A noticeable characteristic is the occurrence of 


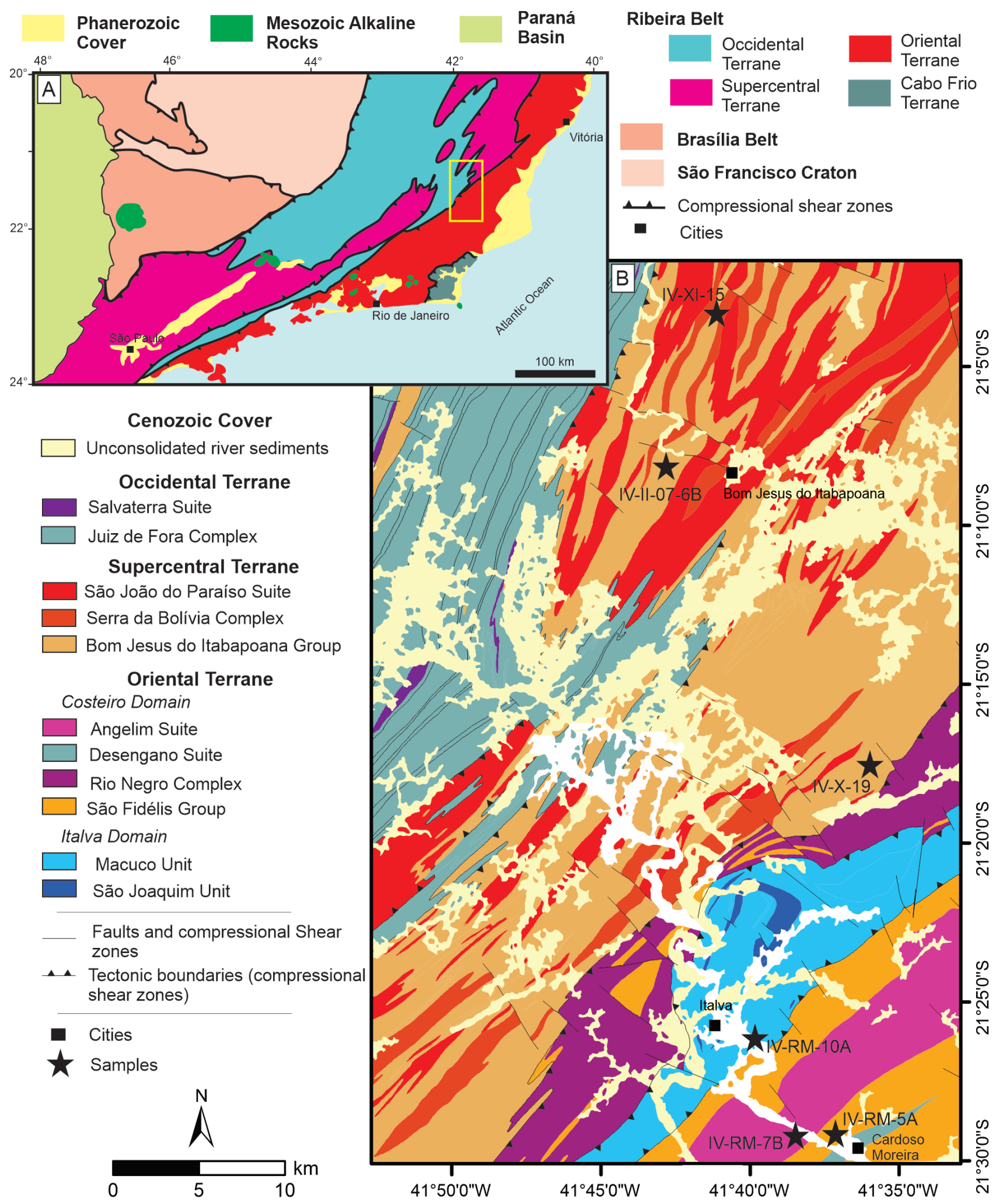

Figure 1. Geological contextualization. A) Simplified tectonic map of the southeastern region of Brazil (modified from Heilbron et al., 2004, after Heilbron et al., 2017, 2020); B) Simplified geological map of the Itaperuna region in the northwest of Rio de Janeiro (modified from Duarte et al., 2012, after Heilbron et al., 2020).

Figura 1. Contextualização geológica. A) Mapa tectônico simplificado da região sudeste do Brasil (modificado a partir de Heilbron et al., 2004 com base em Heilbron et al., 2017, 2020); B) Mapa geológico simplificado da região de Itaperuna no noroeste fluminense (modificado a partir de Duarte et al., 2012, após Heilbron et al., 2020). 
intrusive contacts with the metasedimentary rocks of the Sao Fidelis Group.

The Italva Domain consists of a metavolcano-sedimentary succession called as the Italva Group (Machado Filho et al., 1983 - with stratigraphic nomenclature revised by Nogueira, 2012). This unit comprises a (garnet)-biotite leucocratic gneiss interlayered with amphibolite, calc-silicate rocks, and muscovite-sillimanite(garnet)-biotite gneisses. Thick layers of graphite-rich calcitic to dolomitic marbles, interlayed with bands and lenses of amphibolites and metaultramafic rocks are also described.

\section{Materials and methods}

Based on petrographic-petrological analysis of ca. 350 thin-sections, six samples were selected for mineral chemistry analysis in temperature and/or pressure sensitive mineral assemblage or mineral pairs. Three of the selected samples are from the Cambuci Domain (two metabasic rocks - JI-XI-15B; JI-II-07-36B - and one metapelitic rock - IV-X-19, all of them from the Bom Jesus do Itabapoana Group); two samples are from the Costeiro Domain (a metapelite from the São Fidelis Group - IV-MR$5 \mathrm{~A}$ - and an orthogneiss from the Angelim Suite - IV-MR-7B); and one sample from the Italva Domain (amphibolite, Italva, IV-MR-10A). As the analyzed minerals did not show any evidence of zoning, the applied method was to analyze two spots at the core and two spots at the rim of the crystals.

Mineral chemistry data were performed at the Laboratório de Microscopia e Microanálises of Physics-Geology-Chemistry Consortium of the Universidade Federal de Minas Gerais/CDTN by a JEOL electron microprobe, model JXA$8900 \mathrm{RL}$, using $15 \mathrm{kV}$ voltage acceleration and $20 \eta A$ current. Grain cores and rims were analyzed and the results of those with satisfactory closure are reported on the supplementary data.

The mineral structural formula calculations were processed using an Excel worksheet, following the procedures described in Deer et al. (1992). Minpet software, version 2.2, (Richard, 1995) was used for correction of the FeO and $\mathrm{Fe}_{2} \mathrm{O}_{3}$, mineral classification and mineral composition projections on binary and ternary diagrams.

$$
\text { Pressure and temperature values }
$$

were obtained based on conventional geothermobarometry, using softwares such as: GPT (Reche \& Martinez, 1996), for metapelite of both the Cambuci and Costeiro domains, according to the calibration of several authors, which include formulas of thermometers and barometers; Ptmafic (Soto \& Soto, 1995), for metabasic rocks of the Cambuci Domain; and Hb-PI (Holland \& Blund, 1994). The abbreviations of minerals and components follow those suggested by IUGS (Siivola \& Schmid, 2007).

\section{Results}

\section{1 Central Superterrane}

\subsubsection{Cambuci Domain}

From the petrological analysis, a metamorphic pulse $\left(M_{1}\right)$ is characterized by the presence of metamorphic peak minerals (orthopyroxene + clinopyroxene + plagioclase + hornblende for metabasites and garnet + biotite + sillimanite + quartz + spinel) in the main foliation (mylonitic or not), indicating conditions of upper amphibolite and / or granulite facies.

\section{Metabasites}

Metabasites occur as concordant lenses in the metasedimentary unit. They are foliated, have elongated shaped bodies (up to 30 centimeters in length) (Fig. 2A), and are intersected by quartz veins. In some locations, there are bodies of mappable extensions, as in the vicinity of Bom Jesus do Itabapoana (RJ) and São José do Calçado (ES). The metabasites microstructures are characterized by granoblastic (polygonal), nematoblastic and local coronitic textures. They are melanocratic, have heterogeneous fine to medium grain size (Fig. 2B), with mineral compositional variation. Sample JI-II-0736B (Fig. 2C and 2D) displays a granoblastic texture of orthopyroxene, clinopyroxene and plagioclase. Clinopyroxenes grains are partially replaced by hornblende and both, pyroxenes and plagioclase, are surrounded by coronitic garnet. 
There is also the occurrence of vermiform quartz between pyroxenes and plagioclase. Sample JI$\mathrm{XI}$-15B (Fig. 2B) displays a granoblastic texture composed of orthopyroxene, clinopyroxene, hornblende, plagioclase and opaque minerals. In sample JI-XI-15B, an outer corona of hornblende occurs, mainly bordering pyroxenes and opaque minerals, recording a late cooler event. Distincts mineral assemblages (equilibrium) and the related metamorphic event in both samples from Cambuci Domain are shown. $\mathrm{M}_{0}$ event $-\mathrm{Cpx}_{0}+$ $O \mathrm{Ox}_{0}+\mathrm{PI}_{0}+\mathrm{Op}_{0^{\prime}}$ is related to the granoblastic fabric and mineral cores yielded only $M_{0}$ metamorphic temperatures; $\mathrm{M}_{1}$ event $-\mathrm{Pl}_{1} \pm \mathrm{Opx}_{0}$ (unstable) $\pm \mathrm{Cpx}_{0}$ (unstable) $\pm \mathrm{Cpx}_{1}$ (stable) $\pm \mathrm{Opx}_{1}$ (stable) $\pm \mathrm{Hbl} \pm \mathrm{Grt} \pm \mathrm{Op} \pm \mathrm{Qz} \pm \mathrm{Bt}$ is related to the rims of the minerals in granoblastic fabric and overgrowth, recording the thermal peak of $M_{1}$; and $\mathrm{M}_{2}$ event $-\mathrm{Pl}+\mathrm{Hbl}+\mathrm{Cpx}+\mathrm{Opx}+\mathrm{Bt}+\mathrm{Grt}+$ Op related to the rims of the mineral grains and this paragenesis possibly evidences the cooling phase related to the main metamorphic event.

\section{Metapelites}

This Unit consists of metapelites, metagrawackes and paragneiss. The most common lithotype is the (orthopyroxene) (sillimanite) (garnet) -biotite migmatitic banded gneiss, characterized by the centimetric alternation of layers, consisting essentially of mafic minerals such as biotite and quartz or quartz-feldspathic levels (Fig. 3A). The gneissic paleossome is a gray-colored, uneven, fine- to medium-grained rock. Migmatitic structures, such as schlieren, are quite common (Figure 3B), and nebulitic, phlebitic and agmatic structures are rarely found.

Metapelites consist mainly of mylonitic and protomylonitic pelitic rocks, which have porphyroclasts of garnet (poiquiloblasts ranging from 1 to $5 \mathrm{~mm}$ in diameter, with quartz, opaque minerals, biotite and sillimanite inclusions). Garnet rims are partially replaced by biotite. Prismatic fine-grained crystals of sillimanite (Fig. 3C) are oriented according to the main foliation in a quartz-feldspar recrystallized matrix. Spinel occurs within garnet (Fig. 3D) and sometimes it is surrounded by sillimanite. Apatite, spinel, zircon, monazite and rutile occur as accessory minerals.
The last two minerals were only identified with EDS detector. Observed textural features point to the existence of the following mineral assemblages: (1) Grt + $\mathrm{Qz}+\mathrm{Op}+\mathrm{Bt} \pm \mathrm{Sil} \pm \mathrm{Rt}$ $\pm \mathrm{Spl} \pm \mathrm{Opx} \pm \mathrm{Kfs} \pm \mathrm{Pl}+\mathrm{Ap}+\mathrm{Zrn} \pm \mathrm{Mnz}$, core of minerals, considered the best representative of $\mathrm{M}_{1}$ thermal peak; and (2) Grt + Bt + Op + Qz \pm Sil \pm $\mathrm{Opx} \pm \mathrm{PI} \pm \mathrm{Kfs}$ rims of minerals, reflecting cooling phase associated to $M_{1}$.

\section{Mineral chemistry}

Mineral chemistry obtained in the pelitic rocks indicates that garnet is primarily comprised of almandine molecular (Almandine ${ }_{71-68}$; Pyrope ${ }_{27-24 ;}$ Grossular ${ }_{4-3}$; Spessartine ${ }_{7-5}$ ), with higher values in $\mathrm{Fe}^{2+}$ and lower in calcium. The spinel was classified as gahnite due to its high zinc and aluminum contents.

In the metabasic rocks, the pyroxenes did not show compositional variation between cores and rims. Orthopyroxene is classified as enstatite and clinopyroxene as diopside. When plotted on the diagram proposed by Rietmeijier (1983), for the discrimination between igneous and metamorphic orthopyroxenes, it is verified that the metabasites orthopyroxenes plots in the metamorphic field (Fig. 4).

In sample JI-II-07-36B the core is bytownite $\left(A n_{74-87}\right)$ while its rim is labradorite $\left(A n_{52-49}\right)$ in composition. The amphibole composition plots in the iron-pargasite-hornblende field, whereas garnet, which occurs as coronas around pyroxene, consists dominantly of almandine component (Almandine 59-57; Grossular 21-20; Pyrope $_{21-27} ;$ Spessartine $_{3-2}$ ). However, the calcium concentrations for garnets from the metabasic rocks are higher than those from the pelitic rocks. Fe\# contents in biotite ranges between 0.329 and 0.356 for the metabasic rocks and from 0.338 to 0.342 for the metapelitic rocks.

\subsection{Oriental Terrane}

\subsubsection{Costeiro Domain}

For the study of the metamorphism of this domain, orthogneisses samples from the Angelim Suite and paragneisses (metapelites) from the São Fidelis Group were selected. 


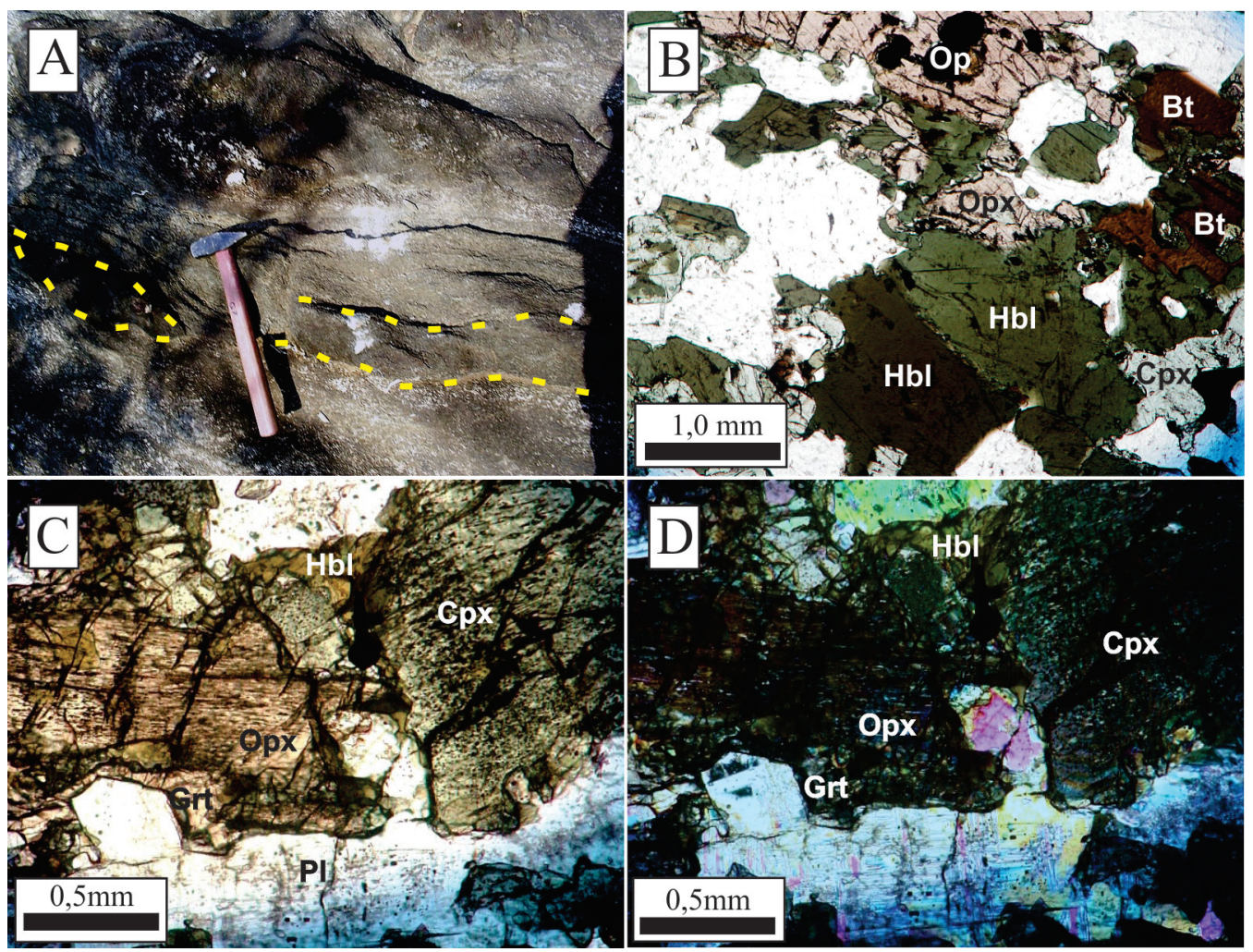

Figure 2. Metabasite of Cambuci Domain. A) Outcrop of elongated shaped metabasite enclave;

B) LPP photomicrograph of metabasite showing granoblastic texture composed of hornblende (Hbl), clinopyroxene (Cpx), orthopyroxene (Opx), plagioclase (Plg) and opaque mineral (Op) - JI-XI-15B sample; C) PPL photomicrograph; and D) PL photomicrograph, both showing metabasite with plagioclase $(\mathrm{Pl})$ and coronitic garnet around clinopyroxene (Cpx) and orthopyroxene (Opx) - JI-II-07-36B.

Figura 2. Fotomicrografias dos litotipos do Domínio Cambuci. A) Afloramento de metabasito alongado; B) Metabasito com textura granoblástica composta de hornblenda ( $\mathrm{Hbl})$, clinopiroxênio (Cpx), ortopiroxênio (Opx), plagioclásio (Plg) e mineral opaco (Op) - amostra JI-XI-15B; C) Fotomicrografia em LPP; e D) Fotomicrografia em LP, ambas mostram o metabasito com plagioclásio (PI) e coronas de granada (Grt) em torno de clinopiroxênio (Cpx) e ortopiroxênio (Opx) JIII-07-36B.

Mineral assemblages of gneisses from both units indicate that M1 metamorphism developed under granulite facies conditions.

\section{Angelim Suite}

Orthogneisses from the Angelim Suite are mainly dark to light grey rocks (Fig. 5A). Its main texture is granoblastic and, in some samples, porphyroblastic (Fig. 5B). Although some garnet porphyroblasts are elongated, most of the grains have rounded shapes (Fig.5C e D); large porphyroblastic crystals of antiperthitic plagioclase are less frequent. The rock matrix is fine to medium grained and consists of xenoblastic quartz and oriented lamellar biotite. Plagioclase has a xenoblastic habit. Apatite, zircon and opaque minerals occur as accessories phases. The occurrence of hornblende-oriented grains is restricted. Two mineral assemblages were observed for the orthogneisses of Angelim Suite (sample IV-RM-7B): (1) Grt+ $\mathrm{Qz}+\mathrm{PI}+\mathrm{Bt}+\mathrm{Op}$, related to the core of the grains - this assemblage is interpreted as corresponding to the $M_{1}$ peak metamorphism; and (2) Grt + Qz+ PI + Bt + Op, related to the rims of the grains and interpreted as related to the cooling phase of $\mathrm{M}_{1}$ metamorphism. 


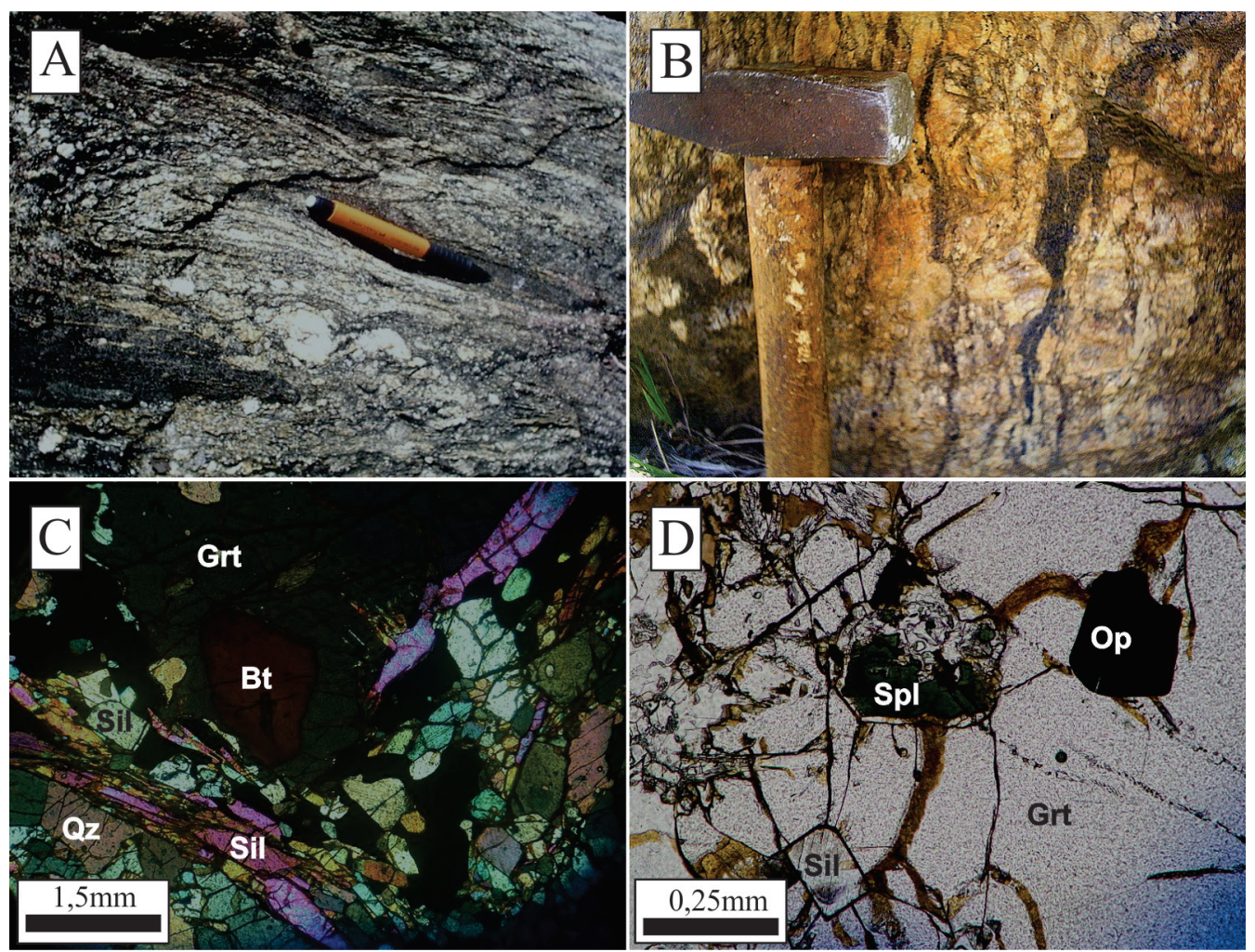

Figure 3. Metapelites of Cambuci Domain. A) Outcrop of gneiss characterized by centimetric alternation of levels consisting essentially of mafic minerals and quartz or quartz-feldspathic levels; B) Outcrop showing schliren migmatitic structure; C) Metapelite photomicrography in PL showing garnet (Grt), biotite (Bt), sillimanite (Sil) and quartz (Qz) IX-X-19 sample; D) Metapelite photomicrography in PL showing spinel (Spl), opaque mineral (Op), and sillimanite (Sil) inclusions in garnet (Grt) - sample IX-X-19.

Figura 3. Metapelitos do Domínio Cambuci: A) Afloramento de gnaisse caracterizado pela alternância de níveis consistindo essencialmente em níveis de minerais máficos e níveis de quartzo ou quartzo-feldspáticos; B) Afloramento mostrando uma estrutura migmatitica do tipo schliren; C) Fotomicrografia de metapelito em LPP mostrando granada (Grt), biotite (Bt), sillimanite (Sil), e quartzo (Qz) - IX-X-19 amostra; D) Fotomicrografia de metapelito em LPP mostrando inclusões de espinélio (Spl), mineral opaco (Op), e sillimanita (Sil) em granada (Grt) - amostra IX-X-19.

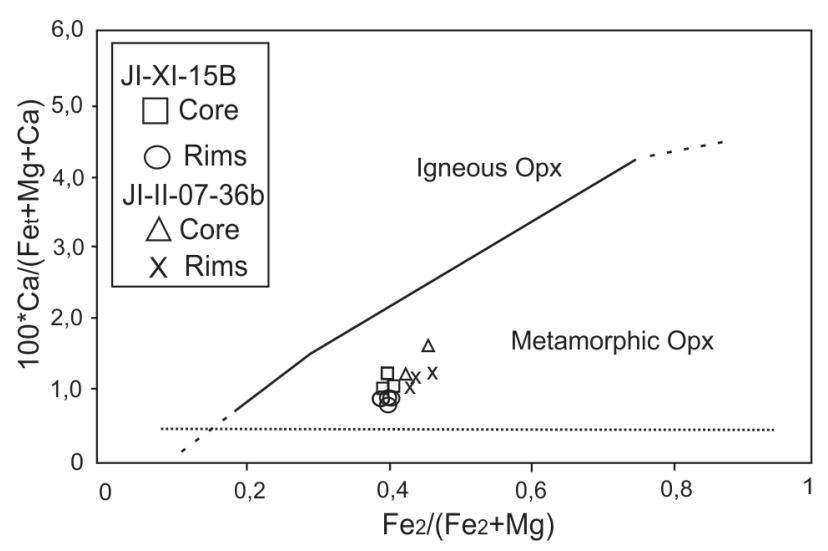

Figure 4. Discrimination between igneous and metamorphic orthopyroxenes (Rietmeijer, 1983) of metabasites from the Cambuci Domain.

Figura 4. Discriminação entre ortopiroxênios ígneos e metamórficos (Rietmeijer, 1983) dos metabasitos do Domínio Cambuci.

\section{Paragneiss of the São Fidelis Group}

The metasedimentary rocks of the São Fidelis Group (Costeiro Domain) are characterized by gneissic structure with localmigmatitic aspect (Fig. 5E). The paleosome mineralogy is composed of garnet porphyroblasts with numerous mineral inclusions (Fig. 5F) which include xenoblastic quartz, oriented biotite, xenoblastic plagioclase grains, opaque minerals and, more rarely, sillimanite and orthoclase crystals. The accessory minerals are apatite and zircon, often showing idioblastic morphology. Two mineral assemblages describe the metamorphism of the paragneiss: (1) PI + Qz + Op + Grt \pm Sil \pm Kfs \pm $R t+Z r n$, related to the core of the grains and $M_{1}$ peak metamorphism.; and (2) Qz + Pl + Grt \pm Kfs, regarding $\mathrm{M}_{1}$ cooling phase. 

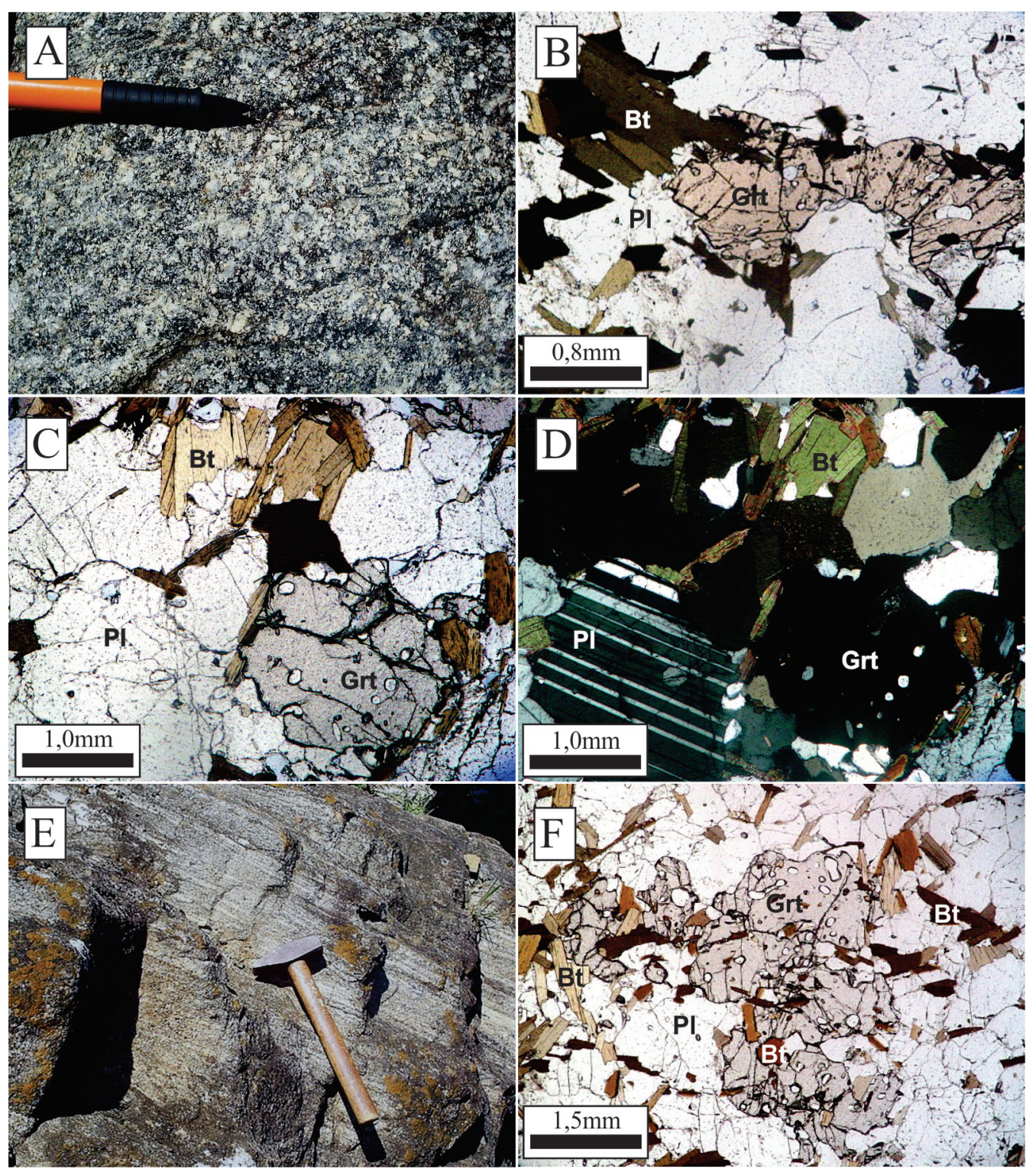

Figure 5. Rocks of Costeiro Domain. A) Orthogneiss outcrop of the Angelim Suite; B) Photomicrograph in PPL showing an elongated shaped garnet (Grt) porphyroblast - sample IV-RM-7B; photomicrographs showing rounded shaped garnet (Grt) porphyroblasts, biotite (Bt) and plagioclase (PI); C) Photomicrograph in PPL; D) Photomicrograph in PL; E) Paragneiss outcrop of the São Fidelis Group; F) Photomicrography in PPL showing garnet (Grt), plagioclase (PI), biotite (Bt) and opaque mineral (Op) - sample IV-RM- 5A.

Figura 5. Rochas do Domínio Costeiro. A) Afloramento de ortognaisse da Suite Angelim; B) Fotomicrografia em LPP mostrando um porfiroblasto de granada (Grt) alongado - amostra IV-RM-7B; fotomicrografias mostrando porfiroblasto de granada (Grt) arredondado, biotita (Bt) e plagioclásio (PI); C) Fotomicrografia em LPP; D) Fotomicrografia em LP; E) Afloramento de paragnaisse do Grupo São Fidélis; F) Fotomicrografia em LPP mostrando (Grt), plagioclásio (PI), biotita (Bt) e minerais opacos (Op) - amostra IV-RM-5A.

\section{Mineral chemistry}

Mineral chemistry results obtained from the Angelim Suite orthogneiss indicate that garnet has dominant almandine composition (Almandine ${ }_{57-}$ ${ }_{59}$; Pyrope ${ }_{7-10}$; Grossular ${ }_{11-24 ;}$ Espessartine ${ }_{6-11}$; Andradite ${ }_{7-1.5}$ ) with systematic variations that show increasing levels of grossular component from core to rim. Plagioclase has andesine composition $\left(\mathrm{An}_{38-46}\right)$ with rims being slightly more calcic than cores. Biotite is iron-rich (Fe\# ranging from 0.63 to 0.64 ) and its composition is projected in the field of annite-siderophyllite.

Mineral chemical analysis for the paragneisses of the São Fidelis Group showed that garnet is unzoned and display almandinerich composition (Almandine ${ }_{72-66}$; Pyrope ${ }_{19-16 ;}$ Grossular $\left.{ }_{14-10}\right)$. Plagioclase is labradorite $\left(\mathrm{An}_{45-54}\right)$ with more sodic composition towards its rims. The composition of biotite (annite-siderophyllite field) is given by Fe\# of 0.43 . 


\subsubsection{Italva Domain}

Because of the restrict occurrence of metapelitic rocks in this Domain, the study of metamorphism in this area was focused on the metabasic rocks (orthoamphibolites). The observed paragneisses and mineral assemblages are limited due to the occurrence of a few mineral phases. In this Domain, it was possible to define only one metamorphic pulse $\left(M_{1}\right)$ contemporary to the main phase of deformation $\left(D_{1}+D_{2}\right)$. Generally, the amphibolite occurs interlayered with gneiss in a millimetric to centimetric banding (Fig. 6A). Metaultramafic, marbles and calcsilicatic rocks occur in the Italva Domain. The amphibolites are fine-grained and characterized by homogeneous and massive structures, with equigranular granoblastic and nematoblastic textures (Fig. 6C).
The essential mineralogical composition is given by hornblende with polygonal contacts, that occur as prismatic crystals lacking twinning.; Clinopyroxene has tabular-prismatic to hipidioblastic habit, and is described in samples without opaque minerals (Fig. 6B, 6C and 6D). Titanite, opaque minerals, biotite, quartz and rutile are accessory phases. Biotite is very restricted and only develops at hornblende crystals rims.

Mineral association (1) is defined by mineral cores of the assemblage hornblende + plagioclase \pm clinopyroxene \pm opaque minerals + titanite + quartz that record $M_{1}$ metamorphic peak. The rims of these minerals (mineral assemblage 2) were analyzed as recording the cooling of this metamorphic event. Sample IV-RM-10A was selected for performing mineral analyses.

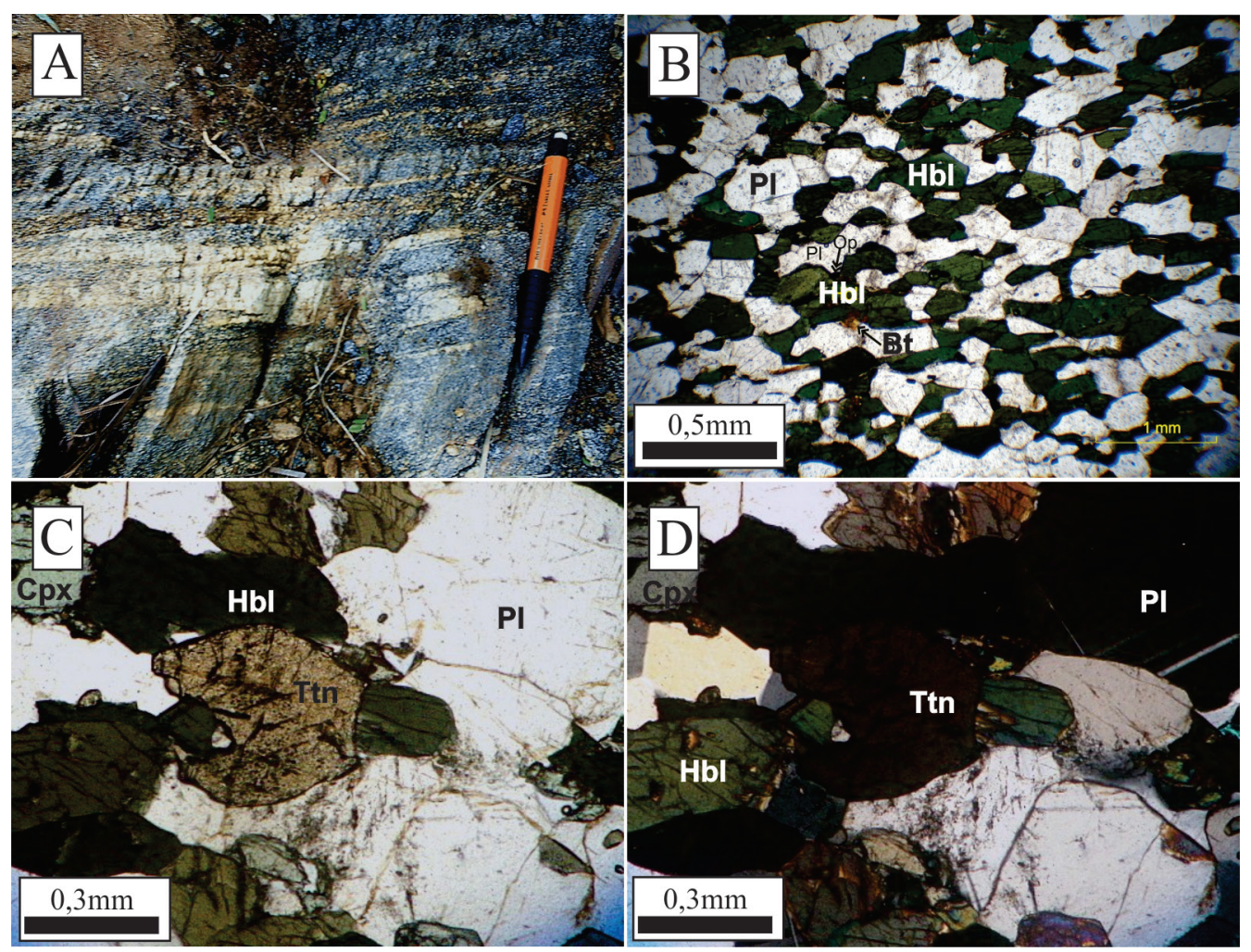

Figure 6. Metabasites from the Italva Domain. A) Outcrop of amphibolite interlayered with gneiss, Italva (RJ); B) Photomicrograph in PPL showing hornblende $(\mathrm{Hbl})$, plagioclase $(\mathrm{PI})$ and opaque mineral $(\mathrm{Op})$ - sample IV-VIII-10; C) Photomicrographs PLL; D) Photomicrographs in PL showing hornblende ( $\mathrm{Hbl})$, clinopyroxene (Cpx), plagioclase (PI) and titanite (Ttn) - sample IV-RM-10A.

Figura 6. Metabasitos do Domínio Italva. A) Afloramento de anfibolito com intercalações de gnaisse em Italva (RJ); B) Fotomicrografia em LPP mostrando hornblenda ( $\mathrm{Hbl}$ ), plagioclásio (PI) e minerais opacos (Op) - amostra IV-VIII-10; C) Fotomicrografias LPP do metabasito; (D) Fotomicrografias em LP mostrando hornblenda (Hbl), clinopiroxênio (Cpx), plagioclásio (PI) e titanita (Ttn) - amostra IV-RM-10A. 


\section{Mineral chemistry}

The mineral chemistry data obtained from sample IV-RM-10A shows that minerals do not display any chemical zoning. The obtained compositions for the amphiboles are classified as Fe-pargasite-hornblende. The plagioclases have andesine compositions (Anorthite ${ }_{40-35}$ ) and the clinopyroxene is represented by diopside.

\section{Temperature and pressure calculations}

For the Cambuci Domain metabasites, temperatures related to the mineral assemblage (0) were obtained from Wood \& Banno (1973), resulting in $788{ }^{\circ} \mathrm{C}$ (Table 1 ). In the mineral assemblage (1) - peak of metamorphism temperature values were obtained through the following geothermometers: clinopyroxeneorthopyroxene (Wood \& Banno, 1973), hornblende-plagioclase (Holland \& Blund, 1994), garnet-biotite (Thompson, 1976; Ferry \& Spear, 1978; Perchuk et al., 1985), yielding $752{ }^{\circ} \mathrm{C}$ in average. Temperatures of mineral assemblage (2) were obtained from clinopyroxene-garnet (Ellis \& Green, 1979), clinopyroxene-orthopyroxene (Wood \& Banno, 1973), hornblende-plagioclase (Holland \& Blund, 1994) and garnet-biotite geothermometers (Thompson, 1976; Ferry \& Spear, 1978; Perchuk et al., 1985) resulting in 705 ${ }^{\circ} \mathrm{C}$ in average (Table 01). Pressure values were obtained from the clinopyroxene-plagioclasegarnet (Eckert et al., 1991), clinopyroxeneplagioclase-quartz geobarometers (Ellis, 1980), resulting in an average of $6.9 \mathrm{kbar}$ (equillibrium 2) (Table 02).

For the metapelitic rock (sampleIX-X-19) the metamorphic peak temperature average reached $718^{\circ} \mathrm{C}$, considering the follow geothermometers (values in Table 1): Thompson (1976); Ferry \& Spear (1978); Perchuck et al. (1985). A pressure of $6.62 \mathrm{kbar}$ was obtained from the Bohlen et al. (1983) geobarometer: (Table 02). Using data from rims of the minerals, the obtained average values were $650{ }^{\circ} \mathrm{C}$ and $5.8 \mathrm{kbar}$ for the same geothermometers and geobarometers (Tables 1 and 2).

$M_{1}$ temperature conditions of the orthogneisses from the Angelim Suite were accessed by the application of conventional geothermometry on equilibrium mineral assemblages (1) and (2). Garnet-biotite geothermometer calculations (Thompson, 1976; Ferry \& Spear, 1978; Perchuk et al., 1985) yielded an average of $784{ }^{\circ} \mathrm{C}$ (mineral assemblage 1), regarded as the minimum temperature value for $M_{1}$ metamorphic peak, and $668{ }^{\circ} \mathrm{C}$ (mineral assemblage 2) for the cooling stage (Table 01). Pressure values, obtained by the application of the garnet-hornblende geobarometer (Kohn \& Spear, 1990), are 8.4-9.0 kbar, for $M_{1}$ metamorphic peak (mineral assemblage 1), and ranges between 6.8 to 7.5 kbar for mineral assemblage (2) (Table 02).

$M_{1}$ metamorphism temperatures obtained for mineral assemblage (1) and (2) of the São Fidélis Group paragneisses were calculated from garnet-biotite thermometers (Thompson, 1976; Ferry \& Spear, 1978; Perchuk et al., 1985). $M_{1}$ peak metamorphism reached temperatures of $752{ }^{\circ} \mathrm{C}$ and its cooling temperature were about $642{ }^{\circ} \mathrm{C}$ (Table 01). The geobarometer grt $+\mathrm{pl}+$ als + qz (Hodges \& Spear, 1982), used to estimate the pressure, generated the following results: approximately 8.2 kbar for mineral assemblage (1); and about $6.44 \mathrm{kbar}$ for mineral assemblage (2) (Table 02).

The calibration used for M1 peak metamorphism in amphibolites of the Italva Domain was the hornblende-plagioclase (Holland \& Blund, 1994) and hornblende (Otten, 1984) geothermometers and the hornblende geobarometer (Hollister et al., 1987; Schmidt, 1992). Mineral cores are considered to retain the nearest composition to that of $M_{1}$ metamorphic peak equilibrium. Application of the geothermobarometer on these cores yielded values around $735^{\circ} \mathrm{C}$ and $6.78 \mathrm{kbar}$ (Tables 01 and 02). At the rims of the same mineral grains, and using the same calibration, the average temperature and pressure values, obtained for the probable cooling phase, was ca. $715^{\circ} \mathrm{C}$ and $6.76 \mathrm{kbar}$ (Tables 01 and 02). Therefore, there are not significant differences between temperature values recorded by minerals cores and rims. It is possible that, because of the retrograde exchanging reactions, mineral cores have been partially reequilibrated after peak conditions. 
Table 1. Temperature estimates obtained for the rocks of the Oriental Terrane (Costeiro and Italva domains) and the Central Superterrene (Cambuci Domain) of the Ribeira Belt.

Tabela 1. Estimativas de temperatura obtidas para as rochas do Terreno Oriental (domínios Costeiro e Italva) e do Superterreno Central (Domínio Cambuci) da Faixa Ribeira.

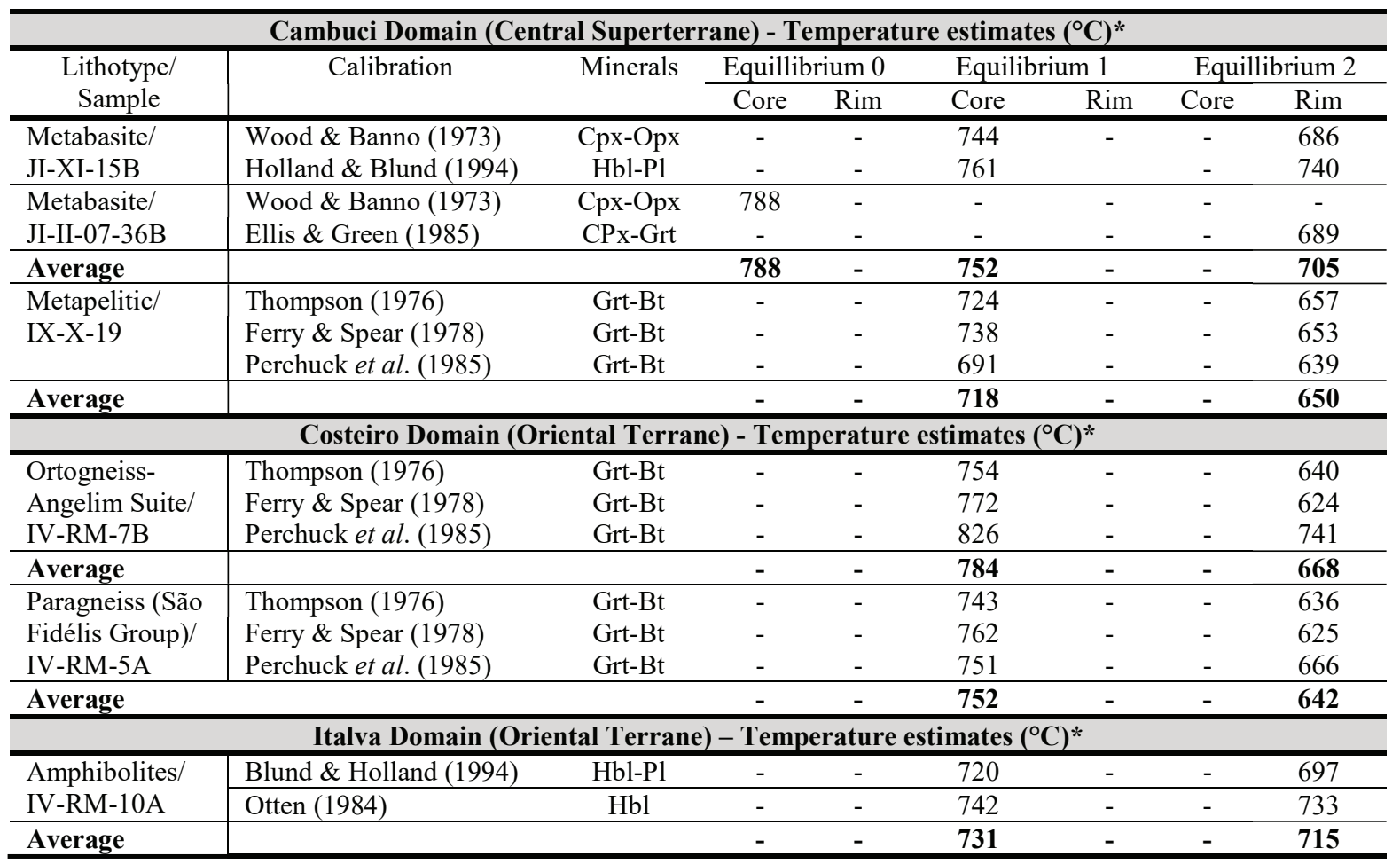

*Constant $\mathrm{P}$ of $7 \mathrm{kbar}$ for equillibrium 0 and $6 \mathrm{kbar}$ for equillibrium 1 and 2.

Table 2. Pressure estimates obtained for the rocks of the Oriental Terrane (Costeiro and Italva domains) and the Central Superterrene (Cambuci Domain) of the Ribeira Belt.

Tabela 2. Estimativas de Pressão obtidas para as rochas do Terreno Oriental (domínios Costeiro e Italva) e do Superterreno Central (Domínio Cambuci) da Faixa Ribeira.

\begin{tabular}{|c|c|c|c|c|c|c|c|c|}
\hline \multicolumn{9}{|c|}{ Cambuci Domain (Central Superterrane) - Pressure estimates (kbar)* } \\
\hline \multirow{2}{*}{$\begin{array}{c}\text { Lithotype/ } \\
\text { Sample }\end{array}$} & \multirow{2}{*}{ Calibration } & \multirow{2}{*}{ Minerals } & \multicolumn{2}{|c|}{ Equillibrium 0} & \multicolumn{2}{|c|}{ Equilibrium 1} & \multicolumn{2}{|c|}{ Equillibrium 2} \\
\hline & & & Core & Rim & Core & Rim & Core & Rim \\
\hline Metabasite/JI- & Ellis (1980) & Cpx-Pl-Qz & - & - & - & - & - & 7.76 \\
\hline II-36B & Eckert et al. (1991) & Cpx-Pl-Grt & - & - & - & - & - & 6.05 \\
\hline Average & & & - & - & - & - & - & 6.9 \\
\hline $\begin{array}{l}\text { Metapelitic/ IX- } \\
\text { X-19 }\end{array}$ & Bohlen et al. (1983) & Grt-Ilm & - & - & 6.62 & - & - & 5.8 \\
\hline Average & & & - & - & 6.62 & - & - & 5.8 \\
\hline \multicolumn{9}{|c|}{ Costeiro Domain (Oriental Terrane) - Pressure estimates (kbar)* } \\
\hline $\begin{array}{l}\text { Ortogneiss- } \\
\text { Angelim Suite/ } \\
\text { IV-RM-7B }\end{array}$ & Hohn \& Spear (1990) & Grt-Ilm & - & - & $8.4-9.0$ & - & - & $6.8-7.5$ \\
\hline $\begin{array}{l}\text { Paragneiss (São } \\
\text { Fidélis Group)/ } \\
\text { IV-RM-5A }\end{array}$ & Hodges \&Spear (1982) & Grt-Sil-Qz-P1 & - & - & 8.2 & - & - & 6.44 \\
\hline Average & & & - & - & 8.5 & - & - & 6.9 \\
\hline \multicolumn{9}{|c|}{ Italva Domain (Oriental Terrane) - Pressure estimates (kbar)* } \\
\hline Amphibolites/ & Hollister et al. (1987) & $\mathrm{Hbl}$ & - & - & 6.82 & - & - & 6.80 \\
\hline IV-RM-10A & Schmidt (1992) & $\mathrm{Hbl}$ & - & - & 6.74 & - & - & 6.73 \\
\hline Average & & & - & - & 6.78 & - & - & 6.76 \\
\hline
\end{tabular}

*Constant $\mathrm{T}$ of $750{ }^{\circ} \mathrm{C}$ for equillibrium 1 and $730^{\circ} \mathrm{C}$ for equillibrium 2. 


\subsection{P-T Contrasting Information within the terranes of the Ribeira Belt}

Based on the amphiboles composition from the Cambuci and Italva domains, it was possible to compare the obtained data with those from the the Juiz de Fora Domain metabasites Occidental Terrane (Duarte, 1998), as shown in the figure 7. All compositions are projected onto the field of medium and low-pressure terranes (Abukuma - Japan type and Haast River, New Zealand), according to the diagram of Laird \& Albee (1981). The Cambuci Domain amphiboles are projected in the field of the Dalradian Terrane, Scotland (Medium pressure).

\section{Discussion}

Despite of frequent obliteration of textures and mineral assemblages during the evolution of prograde paths (Bohlen, 1987; Harley, 1989; Spear, 1993), it was possible to calculate the temperature and pressure values related to the peak metamorphic conditions and also those related to the adjustments arising from retrograde reactions for rocks of both the Cambuci and Costeiro domains. Calculations performed on metabasites from the Italva Domain are only related to the metamorphic peak.

Temperature and pressure values obtained for the three tectonic domains of the Central and Oriental terranes based on conventional geothermobarometry.

The $P-T$ values obtained in Central Superterrane (Inner Arc) are as follow: Cambuci Domain - metabasic rocks of the Bom Jesus do Itabapoana Group - $\mathrm{M}_{0}$ - granoblastic mineral assemblage $=788{ }^{\circ} \mathrm{C}$; Cambuci Domain metabasic rocks of the Bom Jesus do Itabapoana Group - $M_{1}$ - mineral assemblage $(1)=752^{\circ} \mathrm{C}$ and $6.9 \mathrm{kbar} ; \mathrm{M}_{1}$ - mineral assemblage $(2)=705^{\circ} \mathrm{C}$ and $6.9 \mathrm{kbar}$ - related to retroarc basin of the Central Superterrane; Cambuci Domain - metapelitic rocks of the Bom Jesus do Itabapoana Group $M_{1}$ - mineral assemblage $(1)=718^{\circ} \mathrm{C}$ and 6.62 kbar; $M_{1}$ - mineral assemblage $(2)=650{ }^{\circ} \mathrm{C}$ and $5.8 \mathrm{kbar}$ - related to retroarc basin of Central Superterrane;
The P-Tvalues obtained in Oriental Terrane are as follow: Costeiro Domain - orthogneisses of the Angelim Suite: $M_{1}$ - mineral assemblage $(1)=785^{\circ} \mathrm{C}-8.4$ to $9.0 \mathrm{kbar}$; and $M_{1}$ - mineral assemblage $(2)=674{ }^{\circ} \mathrm{C}$ and 6.8 to $7.5 \mathrm{kbar}$ - related to Rio Doce Arc of Oriental Terrane; Costeiro Domain - metapelitic rocks of the São Fidélis Group: $M_{1}-$ mineral assemblage $(1)=$ $750{ }^{\circ} \mathrm{C}$ and 8.2 and $M_{1}$ - mineral assemblage $(2)=640{ }^{\circ} \mathrm{C}$ and $6.64 \mathrm{kbar}$ - related to retroarc basin of Oriental Terrane; and Italva Domain - metabasic rocks of the Italva Group - $M_{1}-$ mineral assemblage $(1)=735^{\circ} \mathrm{C}$ and $6.78 \mathrm{kbar}$; and $\mathrm{M}_{1}$ - mineral assemblage $(2)=705^{\circ} \mathrm{C}$ and $6.76 \mathrm{kbar}$ - related to retroarc basin of Oriental Terrane.

Textures and mineral assemblages of the metabasites and metapelites of the Cambuci (Central Superterrane) record the occurrence of two distinct metamorphic events, named $M_{0}$ and $M_{1}$. The first event $\left(M_{0}\right)$ is recorded by Opx $+C p x$ $+\mathrm{PI}+$ Op in a granoblastic texture and developed under conditions of high temperatures $\left(788^{\circ} \mathrm{C}\right)$ and most likely low to low/medium pressures, according to petrography evidence, such as euhedral pyroxenes and plagioclase, thus suggesting an igneous morphology and pressure conditions below those of coronitic garnet formation - $P<4-6$ kbar. The second event $\left(M_{7}\right)$ is characterized by $\mathrm{Opx}+\mathrm{Cpx}+\mathrm{Pl}+\mathrm{Grt}+\mathrm{Op}+$ $\mathrm{Qz}+\mathrm{Hbl}+\mathrm{Bt}$, developed under conditions of high temperatures $\left(752{ }^{\circ} \mathrm{C}\right)$ and medium pressures (conditions above those of garnet formation - $\mathrm{P}$ $\sim 6.9$ kbar)

Textures and mineral assemblages of rocks of the Costeiro and Italva Domains (Oriental Terrane) record only one metamorphic event $\left(M_{1}\right)$ : peak metamorphic conditions of the granulite facies for the Costeiro Domain ( $T$ : 752-784 ${ }^{\circ}$ C; P. 9 kbar) and of the amphibolite/ granulite facies for the Italva Domain ( $\mathrm{T}$ : 735 $705^{\circ} \mathrm{C}$; $6.78 \mathrm{kbar}$ ). The peak temperature values of $M_{1}$ in Italva Domain are slightly lower when compared to those described above. This domain was subjected to transitional conditions between those of upper amphibolite and granulite facies. There is no significant change in the obtained core $\left(\mathrm{T} \sim 735^{\circ} \mathrm{C}\right)$ to $\operatorname{rim}\left(\mathrm{T} \sim 705^{\circ} \mathrm{C}\right)$ temperature. 

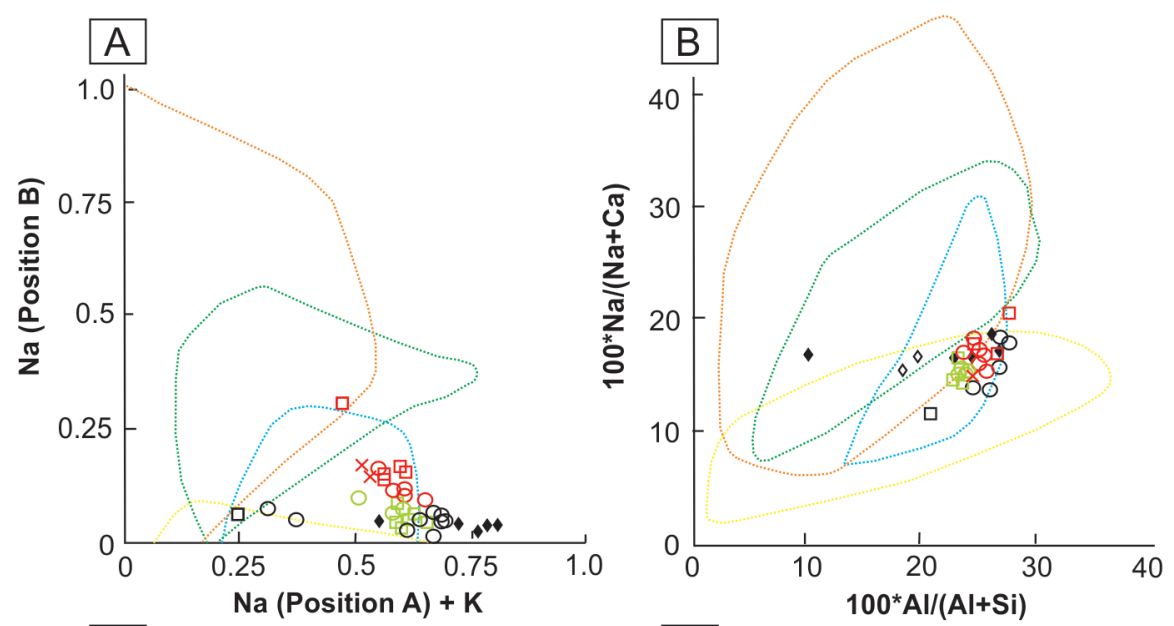

Metamorphic facies of $P$ (Sambagawa, Japan and Franciscan, California)
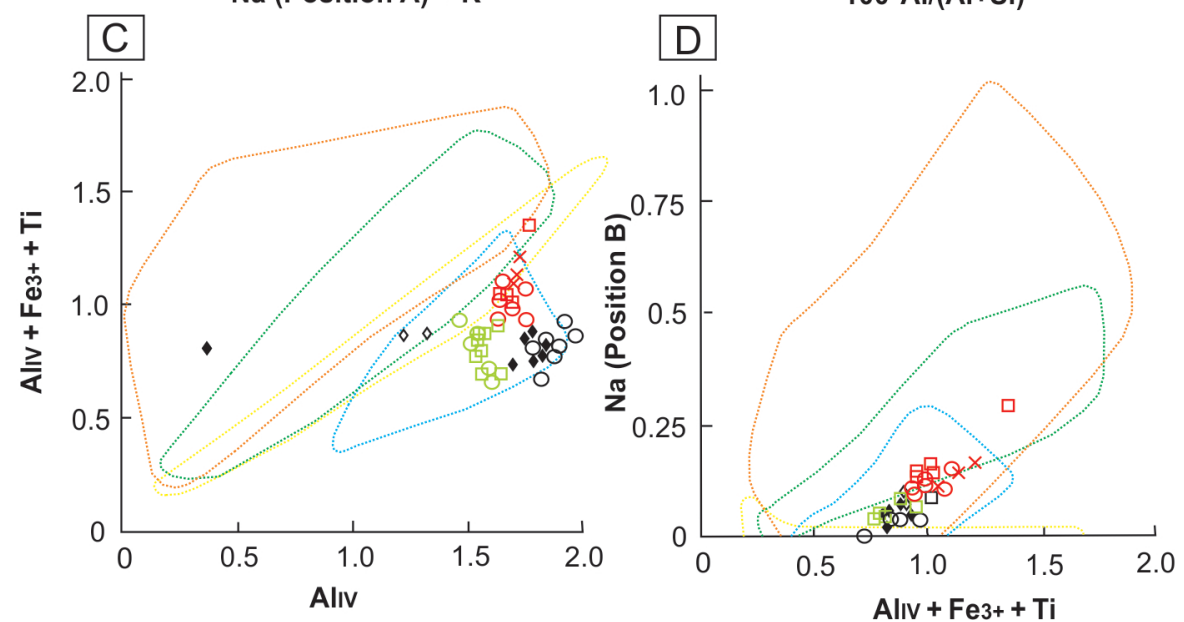

Metamorphic facies of medium $\mathrm{P}$ (Dalradian Terrane, Scotland)

Metamorphic facies of medium P (Haast River Terrane, New Zealand)

Metamorphic facies of low P (Abukuma Terrane, Japan)

\section{口о× Cambuci Domain}

口० Italva Domain

प0 Juiz de Fora Domain

Figure 7. Diagrams showing the projections of amphibole compositions in metabasic rocks from the Cambuci Domain (Central Superterrane): amphibolite of Italva Domain (Oriental Terrane) and mafic ganulites of Juiz de Fora Domain (Occidental Terrane - Duarte, 1998). A) $\mathrm{Na}$ (position B) $\times \mathrm{Na}$ (position A) + K; B) 100* Na/(Na+Ca) x 100*Al/(Al+Si); C) $\mathrm{Al}_{\mathrm{IV}}+\mathrm{Fe}^{3+}+\mathrm{Ti} \times \mathrm{Al}_{\mathrm{IV}}$; D) $\mathrm{Na}$ (position $\left.\mathrm{B}\right) \times \mathrm{Al}_{\mathrm{IV}}+\mathrm{Fe}^{3+}+\mathrm{Ti}$. Fields of different compositions of pressure are defined by Laird \& Albee (1981).

Figura 7. Diagramas mostrando as projeções das composições de anfibólio nas rochas metabásicas do Domínio Cambuci (Superterreno Central): anfibolitos do Domínio Italva (Terreno Oriental) e ganulitos máficos do Domínio Juiz de Fora (Terreno Ocidental - Duarte, 1998). A) Na (posição B) x Na (posição A) + K; B) 100*Na/(Na+Ca) x 100*Al/(Al+Si); C) $\left.\mathrm{Al}_{I V}+\mathrm{Fe}^{3+}+\mathrm{Ti} \times \mathrm{Al}_{I V} ; \mathrm{D}\right) \mathrm{Na}$ (posição B) $\times \mathrm{Al}_{I V}+\mathrm{Fe}^{3+}+\mathrm{Ti}$. Campos de diferentes composições de pressão são definidos por Laird \& Albee (1981).

According to Harley (1989), near-isobaric cooling models (IBC) in mafic granulites can generate coronitic textures with secondary garnet in orthopyroxene-plagioclase contact or overgrowth of late garnet. However, in the studied region, conventional geothermometry calculations indicates that coronitic garnet has developed approximately at the same temperature (peak $M_{1}$ ). These textures usually result from the intersection of multivariate reactions represented by the simplified one: Opx + PI = Qz + Grt + Cpx (Spear, 1993). Such reactions were mainly operated by changes in pressure: from low pressure $\left(\mathrm{M}_{0}\right)$ to medium pressure $\left(M_{1}\right)$ conditions. These data indicate a stage of isothermal compression on the prograde P-T-t path of the rocks of the Cambuci Domain.

Supracrustal rocks of Bom Jesus do Itabapoana Group (Cambuci Domain), which includes the metabasites and metapelites studied, are considered as components of a forearc basin during the evolution of Ribeira Orogen. Thus, it is suggested that $M_{0^{\prime}}$ a low-P/high-T event, recorded only in rocks of Cambuci Domain (Central Superterrane), caused the evolving magmatic arc and the mafic rocks intrusions. Once collision with the Occidental Terrane started, overthrusting provided conditions to the development of a medium $\mathrm{P}$ metamorphism $\left(M_{1}\right)$ in all tectonic domains, different to the Italva 
Domain, which was not in a great depth. In such a model, is suggested (Fig. 8) for the Cambuci Domain of Central Superterrane a anticlockwise P-T-t path near-Isobaric Cooling (IBC), according to the model proposed by Bohlen (1987) and Harley (1989). Harley (1989) determined that most of the IBC granulites resided in the crust (lower or middle depth) for a long period of geological time. Due to lack of absence of evidence, P-T-t paths for the other two domains of Oriental Terrane could not be defined.

The metamorphic conditions recorded for the end of the $M_{1}$ stage in Juiz de Fora Domain were $\mathrm{T}>700-750{ }^{\circ} \mathrm{C}$ and $\mathrm{P}=6-7 \mathrm{kbar}$ (Duarte, 1998; Duarte et al., 2000). Mo showed remarkably similar pressure conditions to Central Superterrane. The results show that, regardless of the tectonic domain, the projection of the values in the diagram from Laird \& Albee (1981) is predominantly in low-pressure terrane (Abukuma-Japan). Data from Cambuci Domain tend to a projection of the medium pressure terrane (Haast River - New Zealand and Dalradian - Scotland). These observations may suggest that a regional event has occurred, after $\mathrm{M}_{1}$, where the system rebalances to lower pressure conditions.

In a regional context, some authors obtained geothermobarometer data for the AraçuaíRibeira Orogen System, which can be related with Oriental Terrane and Central Superterrane of Ribeira Belt and support the data in the present study.

Karniol et al. (2009) analyzed granulites located west of Itaperuna (RJ) with temperature ranging between 754 and $775{ }^{\circ} \mathrm{C}$ and pressure ranging between 7.9 and $8.6 \mathrm{kbar}$ and granulites located east of Itaperuna with temperature values from 702 to $722^{\circ} \mathrm{C}$ and pressure values from 8.0 to 9.1 kbar. Relatively lower temperatures and pressures, between 50 to $100{ }^{\circ} \mathrm{C}$ and between 2.0 to $3.0 \mathrm{kbar}$, were obtained for the aluminous gneisses that emerge between Itaperuna

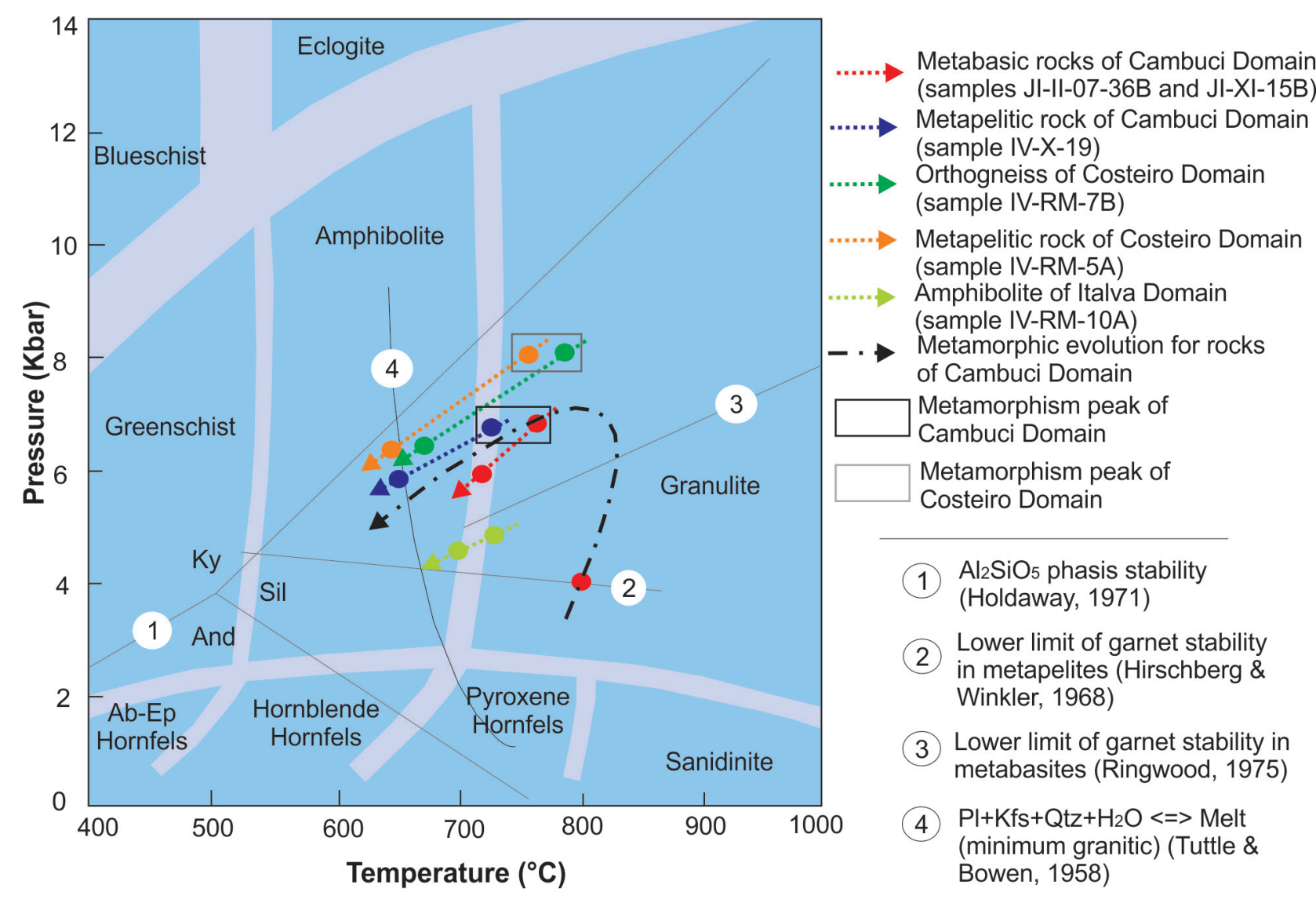

Figure 8. P-T path of the rock types of Cambuci (Central Superterrane), Costeiro and Italva domains (Oriental Terrane). Figura 8. Trajetórias $P-T$ das rochas dos domínios Cambuci (Superterreno Central), Costeiro e Italva (Terreno Oriental). 
and Italva. According to Santos et al. (2011), migmatites and granulites of the central- northern region of the state of Rio de Janeiro reached the metamorphic peak of approximately $850{ }^{\circ} \mathrm{C}$ and pressure of $8 \mathrm{kbar}$.

Richter et al. (2016) obtained data from Nova Venécia Complex (Araçuaí Orogen), interpreted as a retroarc basin. These data are associated to a metasedimentary migmatitic granulitic rocks yield a metamorphic peak at 750 to $850^{\circ} \mathrm{C}$ and 5.3 to $7.5 \mathrm{kbar}$ and retrograde metamorphism at 640 to $800^{\circ} \mathrm{C}$ and 6 kbar. Melo et al. (2017) obtained for the metamorphic peak of the S-type granite Carlos Chagas batholith (Araçuaí Belt) metamorphic temperature peak of 790 to $820^{\circ} \mathrm{C}$ and pressure of 9.5 to 10.5 kbar and $770{ }^{\circ} \mathrm{C}$ and $6.6 \mathrm{kbar}$ for retrograde metamorphism. Medeiros Junior et al. (2017) obtained for metamorphic peak in granulites of Juiz de Fora and Andrelândia group in the region of Abre Campo and Manhuaçu, Minas Gerais, temperature ranging from $748{ }^{\circ} \mathrm{C}$ and $870{ }^{\circ} \mathrm{C}$ and pressures between 5.7 and 7.5 kbar. Gouvêa et al. (2020) estimated for the metamorphic peak of opx bearing metatonalite, related to Rio Doce Arc, temperature about $670{ }^{\circ} \mathrm{C}$ to $860^{\circ} \mathrm{C}$ and pressure from 5.24 to 10.2 kbar.

\section{Conclusions}

Important contributions were done with this work: a) It was detected in the lower Cambuci Domain a previous $M_{0}$ stage, possibly developed during the Rio Doce-Serra da Bolívia arc development; $b$ ) The collisional $M_{1}$ was calibrated for Precambrian rocks of Central Superterrane and Oriental Terrane in northwestern region of the state of Rio de Janeiro, with temperatures and pressures of $752-718{ }^{\circ} \mathrm{C}$ and $6.62 \mathrm{kbar}$ (Cambuci Domain), $752{ }^{\circ} \mathrm{C}$ and 8.2 kbar (São Fidélis Suite - Costeiro Domain), $784^{\circ} \mathrm{C}$ and 8.49.0 kbar (Angelim Suite - Costeiro Domain) and $731^{\circ} \mathrm{C}$ and $6.78 \mathrm{kbar}$ (Italva Domain), compatible with expected upper plates when compared with modern orogenic belts; c) The estimated decompression rate is possibly influenced by erosion and isostasy, showing that the high metamorphic terranes of the Ribeira Belt, mainly Central Superterrane, resided in a deeper crust; and d) Cambuci domain temperature is related to those of high temperature granulites, suggesting anticlockwise P-T-t path and a near-isobaric cooling (IBC) terrane.

This study is one of the pioneers in the approach to the metamorphic contrasting and evolution of the Central Superterrane and Oriental Terrane of the Ribeira Belt, in granulite to upper amphibolite facies, during the Brasilian Orogeny, and consequently a contribution to the understanding the Gondwana west amalgamation.

Acknowledgement. Our thanks CNPq for supporting fieldwork and mineral chemical analyzes (GM/GD-Cotas do Programa de PósGraduação - process number 133529/2007-0). We thank teachers, students (field stages) and researchers from the Geology Faculty of UERJ, which over the past few years, contributed to intensive geological mapping in northwestern region of the state of Rio de Janeiro. We also thank the technician Luis Garcia, who assisted and supported data obtainment, and Professor Aba Cohen Persiano from Laboratório de Microanálises - Instituto de Ciências Exatas UFMG.

\section{References}

Almeida, F.D., Hasui, Y., Brito Neves, B.D. \& Fuck, R.A. 1977. Províncias estruturais brasileiras. In: SIMPÓSIO DE GEOLOGIA DO NORDESTE, 8., 1977, Campina Grande. Anais... Campina Grande, SBG, p. 363-391.

Almeida, F.F.M. 1971. Geochronological Division of the Precambrian of South America. Revista Brasileira de Geociências, 1(1): 13-21.

Almeida, F.F.M., Amaral, G., Cordani, U.G. \& Kawashita, K. 1973. The Precambrian evolution of the South American Cratonic Margin South of Amazonas River. In: Nairn, A.E. \& Stille, F.G. (Eds.). The Ocean Basin and Margins. New York, Plenum, p. 411-466.

Almeida, J.C.H. 2000. Zonas de cisalhamento dúctil de alto grau do médio vale do Rio Paraíba do Sul. Rio Claro, 190p. Tese de Doutorado, Programa de Pós-graduação em Geologia Regional, Instituto de Geociências e Ciências 
Exatas, Universidade Estadual Paulista.

Almeida, J.C.H., Tupinambá, M.A., Heilbron, M.

\& Trouw, R. 1998. Geometric and kinematic analysis at the central tectonic boundary of the Ribeira belt, southeastern Brazil. In: CONGRESSO BRASILEIRO DE GEOLOGIA, 40., 1998, Belo Horizonte. Anais... Belo Horizonte, SBG, v. 1, p. 32.

Batista, J.J. 1984. Caracterização dos processos geológico-evolutivos pré-cambrianos na região de São Fidelis, norte do Estado do Rio de Janeiro. São Paulo, 123p. Tese de Doutorado, Programa de Pós-graduação em Geociências, Instituto de Geociências, Universidade de São Paulo.

Batista, J.J. 1986. Processos geológicoevolutivos da porção setentrional do Cinturão Ribeira e na área estável adjacente. In: CONGRESSO BRASILEIRO DE GEOLOGIA, 34., 1986, Goiânia. Anais... Goiânia, SBG, v. 2, p. 722-727.

Bohlen, S.R. 1987. Pressure-temperature-time paths and a tectonic model for the evolution of granulites. Journal of Gology, 95: 617-32.

Bohlen, S.R., Wall, V.J. \& Boettcher, A.L. 1983. Experimental investigations and geologic applications of equilibria in the system $\mathrm{FeO}$ $\mathrm{TiO}_{2}-\mathrm{Al}_{2} \mathrm{O}_{3}-\mathrm{SiO}_{2}-\mathrm{H}_{2} \mathrm{O}$. American Mineralogist, 68: 1049-1058.

Brown, M. 2006. Dualily of thermal regimes is the distinticve characteristc of plate tectonics since the Neoarchean. Geology, 34(11): 961964.

Brown, M. 2014. The contribution of metamorphic petrology to understanding lithosphere evolution and geodynamics. Geoscience Frontiers, 5(4): 553-569.

Deer, W.A., Howie, R. \& Zussman, J. 1992. An introduction to the Rock-Forming Minerals (2nd ed). New York, Prentice Hall. 298p.

Duarte, B.P. 1998. Evolução tectônica dos Ortognaisses dos Complexos Juiz de Fora e Mantiqueira na Região de Juiz de Fora: Geologia, Petrologia e Geoquímica. São Paulo, 340p. Tese de Doutorado, Programa de Pósgraduação em Geoquímica e Geotectônica, Instituto de Geociências, Universidade de São Paulo.

Duarte, B.P. (coord.). 2012. Folha Itaperuna,
SF.24-V-C-I: texto e mapa. Belo Horizonte, CPRM-UERJ. PRONAGEO, 137p.

Duarte, B.P., Heilbron, M. \& Campos Neto M.C. 2000. Granulite/ Charnockite from the Juiz de Fora Domain, Central Segment of the Brasiliano-Pan-African Ribeira Belt. Revista Brasileira de Geociências, 30: 358-362.

Duarte, B.P., Tupinambá, M., Marques, R.A., Porto Jr, R., Nogueira, J.R., Heilbron, M., Almeida, J.C.H. \& Gontijo-Pascutti, A.H.F. 2012. Geologia Estrutural e Metamorfismo. In: Duarte, B.P. (Coord.). Folha Itaperuna, SF.24-V-C-I: texto e mapa. Belo Horizonte, PRONAGEOLO. CPRM/ UERJ, p 65-76.

Eckert, J.O., Newton, R.C. \& Kleppa, O.J. 1991. $\triangle H$ of reaction and recalibration of garnetpyroxene-plagioclase-quartz geobarometers in CMAS system by solution calorimetry of stoichiometric mineral mixes. American Mineralogist, 76(1-2): 148-160.

Ellis, D.J. 1980. Osumilite-sapphirine-quartz granulites from Enderby Land, Antartica: P-T conditions of metamorphism, implications for garnet-cordierite equilibria and the evolution of the deep crust. Contributions to Mineralogy and Petrology, 74: 201-210.

Ellis, D.J. \& Green, D.H. 1979. An experimental study of the effect of $\mathrm{Ca}$ upon garnetclinopyroxene $\mathrm{Fe}-\mathrm{Mg}$ exchange equilibria. Contributions to Mineralogy and Petrology, 71: 13-22.

Ferry, J.M. \& Spear, F.S. 1978. Experimental calibration of the partitioning of $\mathrm{Fe}$ and $\mathrm{Mg}$ between biotite and garnet. Contributions to Mineralogy and Petrology, 66: 113-117.

Gouvêa, L.P., Medeiros, S.R., Mendes, J.C., Soares, C.V., Marques, R.A. \& Melo, M.G. 2020. Magmatic activity period and estimation of PT metamorphic conditions of pre-collisional opx-metatonalite from Araçuaí-Ribeira orogens boundary, SE Brazil. Journal of South American Earth Sciences, 99: 102506.

Harley, S.L. 1989. The origins of granulites: a metamorphic perspective. Geology Magazine, 126(3): 215-247.

Heilbron, M. 1993. Evolução tectôno-metamórfica da seção Bom Jardim de Minas-MG - Barra do Piraí-RJ, setor central da Faixa Ribeira. São Paulo. São Paulo, 268p. Tese de Doutorado, 
Programa de Pós-graduação em Geoquímica e Geotectônica, Instituto de Geociências, Universidade de São Paulo.

Heilbron, M., Tupinambá, M., Almeida, J.C.H., Valeriano, C.M., Valladares, C.S. \& Duarte, B.P. 1998. New constraints on the tectonic organization and structural styles related to the Brasiliano collage of the Central Segment of Ribeira Belt, SE Brazil. In: INTERNATIONAL CONFERENCE ON BASEMENT TECTONICS. 14., 1998, Ouro Preto. Anais... Ouro Preto, p. 15-17.

Heilbron, M., Pedrosa-Soares, A.C., Campos Neto, M.C., Silva L.C., Trouw, R.A.J. \& Jansi, V.A. 2004. Província Mantiqueira. In: MantessoNeto, V., A. Bartorelli, A., Carneiro, C.D.R. \& Brito Neves, B.B. (Eds). Geologia do Continente SulAmericano: Evolução da obra de Fernando Flávio Marques de Almeida. São Paulo, Beca, p. 203-234.

Heilbron, M., Mohriak W., Valeriano C.M., Milani E., Almeida J.C.H. \& Tupinambá M. 2000. From collision to extension: the roots of the south-eastern continental margin of Brazil. In: Mohriak, W. \& Talwani, M. (eds), Atlantic Rifts and Continental Margins (v. 115). Washington DC: American Geophysical Union (Geophysical Monograph Series), p. 1-34.

Heilbron, M., Cordani, U. \& Alkmim, F.F. 2017. The São Francisco Craton and Its Margins. In: Heilbron, M., Cordani, U. \& Alkmim, F.F. (Orgs.). São Francisco Craton, Eastern Brazil Tectonic Genealogy of a Miniature Continent. Switzerland, Springer, p. 3-14.

Heilbron, M., Silva, L.G.E., Almeida, J.C.E., Tupinambá, M., Peixoto, C., Valeriano, C.M., Lobato, M., Rodrigues, S.W.O., Ragatky, C.D., Silva, M.A., Monteiro, T., Freitas, N.C., Miguens, D. \& Girão, R. 2020. Proterozoic to Ordovician geology and tectonic evolution of Rio de Janeiro State, SE-Brazil: insights on the central Ribeira Orogen from the new 1:400.000 scale geologic map. Brazilian Journal of Geology, 50(2): 1-25.

Hirschberg, A. \& Winkler, H.G.F. 1968. Stabilitätsbeziehungen zwischen Chlorit, Cordierit und Almandin bei der Metamorphose. Contribution to Mineralogy and Petrology, 18: 17-42.
Hodges, K.V. \& Spear, F.S. 1982. Geothermometry, geobarometry and the $\mathrm{Al}_{2} \mathrm{SiO}_{5}$ triple point at Mt. Moosilauke, New Hampshire. American Mineralogist, 67(11-12): 1118-1134.

Holdaway, M.J. 1971. Stability of andalusite and the aluminium silicate phase diagram. American Journal of science, 271(2): 97-131.

Holland, Y.T. \& Blund, J. 1994. Non-Ideal interactions in calcic amphiboles and their bearing on amphibole-plagioclase thermometry. Contributions to Mineralogy and Petrology, 116: 433-447.

Hollister, L.S., Grissom, G.C., Peters, E.K, Stowell, H.H. \& Sisson, V.B. 1987. Confrrmation of the empirical correlation of $\mathrm{Al}$ in hornblende with pressure of solidification of calc-alkaline plutons. American Mineralogist, 72: 231-239.

Karniol, T.R., Machado, R., Bilal, E. \& Moutte J. 2009. Geotermobarometria de granulitos do Cinturão Ribeira na porção norte do estado do Rio de Janeiro: seção Italva (RJ) Patrocínio do Muriaé (MG). Revista Brasileira de Geociências. 39(3): 519-532.

Kohn, M.J. \& Spear, F.S. 1990. Two new geobarometers for garnet amphibolites, with applications to southeastern Vermont. American Mineralogist, 75: 89-96.

Laird, H. \& Albee, A.L. 1981. Pressuretemperature and time indicators in mafic schist: their application to reconstructing the polymetamorphic history of Vermont. American Journal of Science, 281: 127-175.

Machado, N., Valladares, C.S., Heilbron, M. \& Valeriano, C.M. 1996. U-Pb geochronology of the central Ribeira Belt (Brazil) and implications for the evolution of the Brazilian Orogeny. Precambrian Research, 79(3-4): 347-361.

Machado Filho, L., Ribeiro, M.W., Gonzalez, S.R., Schemini, C.A., Santos Neto, A.S., Palmeira, R.C.B., Pires, I.L., Teixeira, W. \& Castro, H. F. 1983. Geologia. In: RADAMBRASIL. Folhas SF 23/24 Rio de Janeiro e Vitória. Rio de Janeiro, RADAMBRASIL, p. 27-286.

Marques, R.A., Mattos, L.C.N., Marangon, G.R., Melo, M.G., Ferreira, S.L.M., Medeiros Júnior, E.B., Velasco, T.C., Licursi, E.A. \& Bottacin C.D. 2019. Geologia e recursos minerais na região de São João do Paraíso (RJ). Revista Sodebrás, 160(14): 54-58. 
Medeiros Junior, E.B., Jordt-Evangelista, H., Marques R.A., Velasco, T.C. \& Soares, C.C.V. 2017. Geothermobarometry of granulites of the Juiz de Fora Complex and the Andrelândia Group in the region of Abre Campo and Manhuaçu, Minas Gerais, Brazil. Geociências, 36 (3): 437-446.

Melo, M.G., Stevens, G., Lana, C., Pedrosa-Soares, A.C., Frei, D., Alkmim, F.F. \& Alkmin, L.A. 2017. Two cryptic anatectic events within a syncollisional granitoid from the Araçuaí orogen (southeastern Brazil): evidence from the polymetamorphic Carlos Chagas batholith. Lithos 277: 51-71.

Nogueira, J.R. (coord). 2012. Nota Explicativa da Folha São Fidélis - 1:1000.000. Belo Horizonte, CPRM-UERJ/PRONAGEO. 107p.

Otten, M.T. 1984. The origin of brown hornblende in the Artfjället gabbro and dolerites. Contributions to Mineralogy and Petrology, 86: 189-199.

Peixoto, C.A., Heilbron, M. Ragatky, D., Armstrong, R., Dantas, E., Valeriano, C.M., \& Simonitti, A. 2017. Tectonic evolution of the Juvenile Tonian Serra da Prata magmatic arc in the Ribeira belt, SE Brazil: Implications for early west Gondwana amalgamation. Precambrian Reserarch, 302: 221-254.

Perchuk, L.L., Aranovich, L.Y., Podlesskii, K.K., Lavrent'eva, I.V., Gerasimov, V.Y., Fed'Kin, V.V., Kitsul, V.I, Karasakov, L.P. \& Berdnikov, N. V. 1985. Precambrian granulites of the Aldan shield, eastern Siberia, USSR. Journal of Metamorphic Geology, 3(3): 265-310.

Reche, J. \& Martinez, F.J. 1996. GPT: An Excel spreadsheet for thermobarometric calculations in metapelitic rocks. Compurers \& Geosciences, 22(7): 775-184.

Reis, A.P. \& Mansur, K.L. 1995. Sinopse Geológica do Estado do Rio de Janeiro. Niterói, DRM/RJ, Escala 1:400.000.

Richard, L.R. 1995. Mineralogical and petrological, data processing system for Windows, version 2.02. Minpet Geological Software, Quebec.

Richter, F., Lana, C., Stevens, G., Buick, I., PedrosaSoares, A.C., Alkmim, F.F. \& Cutts, K. 2016. Sedimentation, metamorphism and granite generation in a back-arc region: records from Ediacaran Nova Venécia Complex (Araçuaí
Orogen, southeastern Brazil). Precambrian Research, 272: 78-100.

Rietmeijer, F.J.M. 1983. Chemical distinction between igneous and metamorphic ortopyroxenes especially those coexisting with ca-rich clinopyroxenes: a re-valuation. Mineralogical Magazine, 47: 143-151.

Ringwood, A.E. 1975. Composition and Petrology of the Earth's Mantle. New York, McGraw, 618 p.

Santos, T.B. dos, Munhá, J., Tassinari, C.C.G. \& Dias Neto, C.M. 2005. Geotermobarometria de rochas metamórficas na região de São Fidélis, RJ, SE Brasil. In: CONGRESSO DE GEOQUÍMICA DOS PAÍSES DE LÍNGUA PORTUGUESA, 8., 2005, Aveiro. Actas... Aveiro, v. 1, p. 95-95.

Santos, T.M.B. dos, Munhá, J.M., Tassinari, C.C.G., Fonseca, P.E. \& Dias Neto, C. 2011. Metamorphic P-T evolution of granulites in the central Ribeira Fold Belt, SE Brazil. Geosciences Journal, 15(1): 27-51.

Schmidt, M.W. 1992. Amphibole composition in tonalite as a function of pressure: an experimental calibration of the Al-inhornblende barometer. Contributions to Mineralogy and Petrology, 110: 304-10.

Siivola, J. \& Schmid, R. 2007. List of Mineral Abbreviations. In: British Geological Survey. Disponível em: < https://www.bgs.ac.uk/ scmr/docs/papers/paper_12.pdf >. Acesso em 07 ago. 2020.

Silva, W.G., Batista, J.J. \& Thompson, R. 1978. Texto explicativo da Follha Geológica Cambuci. Niterói, DRM/RJ, Escala 1:50.000.

Soto, J.I. \& Soto, V.M. (1995). PTMafic (v. 2.0): Software package for thermometry, barometry, and activity calculations in mafic rocks using an IBM-compatible computer. Computers \& Geosciences, 21(5): 619-652.

Spear, F.S. 1989. Petrologic determination of metamorphic Pressure-Temperature-Time paths. In: Spear, F.S. \& Peacock, S.M. (eds). Metamorphic Pressure-Temperature-Time Paths. American Geophysical, p.1-56.

Spear, F.S. 1993. Metamorphic phase equilibria and pressure-temperature-time paths. New York, Mineralogical Society of America Monograph, 799p.

Spear, F.S., Selverstone, J., Hickmott, D., Crowley, 
P. \& Hodges, K.V. 1984. P-T paths from garnet zoning: A new technique for deciphering tectonic processes in crystalline terranes. Geology, 12: 87-90.

Selverstone, J. \& Spear, F.S. 1985. Metamorphic $\mathrm{P}-\mathrm{T}$ Paths from pelitic schists and greenstones from the south-west Tauern Window, Eastern Alps. Journal of Metamorphic Geology, 3(4): 439-465.

Thompson, A.B. 1976. Mineral reactions in pelitic rocks. II. Calculation of some P-T-X (Fe-Mg) phase relations. American Journal of Science, 276: 425-454.

Tupinambá, M., Teixeira, W., Heilbron, M. \& Basei, M. 1998. The Pan-African/Brasiliano arcrelated magmatism at the Costeiro Domain of the Ribeira Belt, southeastern Brazil: new geochronological and lithogeochemical data. In: INTERNATIONAL CONFERENCE ON BASEMENT TECTONICS, 14., Ouro Preto, Abstracts... Ouro Preto, 12-14.

Tupinambá, M., Teixeira, W. \& Heilbron, M. 2000. Neoproterozoic Western Gondwana assembly and subduction-related plutonism: the role of the Rio Negro Complex in the Ribeira belt, South-eastern Brazil. Revista Brasileira de Geociências, 30(1): 7-11.

Tupinambá, M., Heilbron, M., Duarte, B.P., Nogueira, J.R., Valladares, C.S., Almeida, J.C. H., Eirado, L.G., Medeiros, S.R., Almeida, C.G., Miranda, A., Ragatky, C.D., Mendes, J. \& Ludka, I. 2007. Geologia da Faixa Ribeira setentrional: Estado da Arte e Conexões com a Faixa Araçuaí. Geonomos, 15(1): 67-79.

Tuttle, O.F. \& Bowen, N.L. 1958. Origin of granite in the light of experimental studies in the system NaAlSi $\mathrm{O}_{8}-\mathrm{KAISi}_{3} \mathrm{O}_{8}-\mathrm{SiO}_{2}-\mathrm{H}_{2} \mathrm{O}$. Geological Society of America, 74: 153.
Valladares, C.S. 1996. Evolução geológica do Complexo Paraíba do Sul, no segmento central da Faixa Ribeira, com base em estudos de geoquímica e de geocronologia U-Pb. São Paulo, 168p. Tese de Doutorado, Programa de Pós-Graduação em Geoquímica e Geotectônica, Instituto de Geociências, Universidade de São Paulo.

Winter, J.D. 2014. Principles of Igneous and Metamorphic Petrology. 2nd ed. Harlow, Pearson, $739 \mathrm{p}$.

Wood, B.J. \& Banno, S. 1973. Garnetorthopyroxene and orthopyroxeneclinopyroxene relationships in simple and complex systems. Contribitions to Mineralogy and Petrology, 42: 109-124. 